\title{
AVAIIAÇÃO DE PARÂMETROS QUÍMICOS E BIOLÓGICOS EM DIFERENTES SISTEMAS DE MANEJO DO SOLO.
}

\section{SIIVANA APARECIDA PAVAN FERNANDES \\ Engenheira Agrônoma}

\author{
Orientador: Profa.Dra. ELKE JURANDY BRAN \\ NOGUEIRA CARDOSO
}

\begin{abstract}
Dissertação apresentada à Escola Superior de Agricultura "Luiz de Queiroz", da Universidade de são Paulo, para obtenção do título de Mestre em Agronomia, Área de Concentração: Solos e Nutrição de Plantas.
\end{abstract}

\section{P I R A C I C A B A}

Estado de São Paulo - Brasil

Maio - 1995 


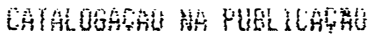

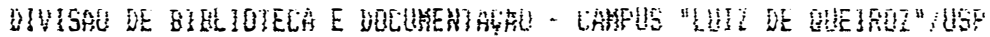

Fernandes, Silyana Agarecida Fañ

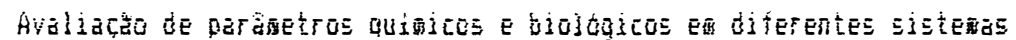

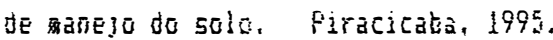

$985 . j 105$

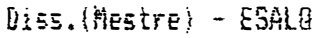

Bitbiogratia.

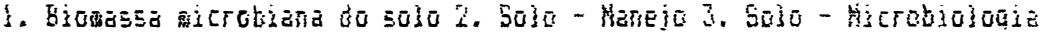

1. Escula Sugerdor de Agricultura luia de Queiró. Firacicaba

CDI 531. मे 
AVALIAÇAO DE PARÂMETROS MICROBIOLOGICOS EM DIFERENTES SISTEMAS DE MANEJO DO SOLO.

\title{
SILVANA APRECIDA PAVAN FERNANDES
}

\author{
Aprovado em: 05/05/1995 \\ Comissão julgadora: \\ Profa. Dra. Elke Jurandy Bran Nogueira Cardoso ESALQ/USP \\ Prof. Dr. Marcio Lambais ESALQ/USP \\ Prof. Dr. Wanderley José de Melo FCAVJ/UNESP
}

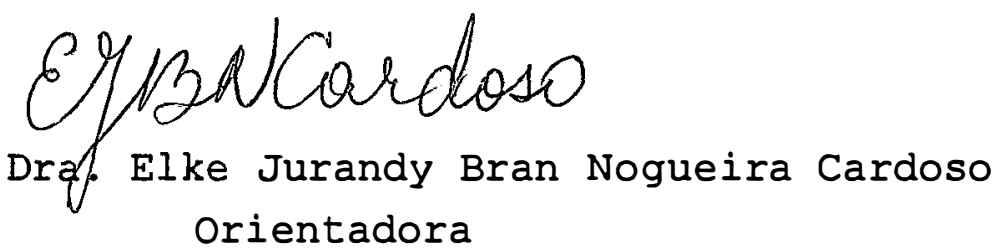




\section{DEDICATÓRIA}

Aos meus pais

$$
\text { SÉRGIO A. L. PAVAN e IZABEL M. PAVAN, }
$$

pelo carinho, compreensão, confiança e incentivo a mim reservados em todos os momentos de minha vida.

Ao meu marido

ODNEI D. FERNANDES

pela compreensão e carinho

a mim reservados. 


\section{AGRADECIMENTOS}

A Profa. Dra. Elke Jurandy Bran Nogueira Cardoso pelo apoio, orientação e incentivo profissional.

A CAPES pelo apoio financeiro na concessão de bolsa de estudo.

Ao Instituto Agronômico de Campinas/SP, pela concessão da área experimental e apoio durante a condução do presente trabalho, especialmente $\mathrm{Dr}$. Orlando Mello de Castro.

Ao Prof. Dr. Wanderley José de Melo (FCAVJ-UNESP) e Prof. Dr. Marcio Lambais (ESALQ-USP) pelas sugestões ao presente trabalho.

Aos técnicos de laboratório Denise e Fernando pelo apoio e convivência na condução do presente estudo:

À bibliotecária Kátia Maria de Andrade Ferraz (ESALQ-USP), pela correção da literatura citada.

Meus agradecimentos a todos os professores, amigos e familiares, que tornaram possivel a realização deste trabalho. 
SUMARIO

RESUMO viii

SUMMARY $\ldots \ldots \ldots \ldots \ldots \ldots \ldots \ldots \ldots \ldots \ldots \ldots \ldots \ldots \ldots \ldots \ldots$

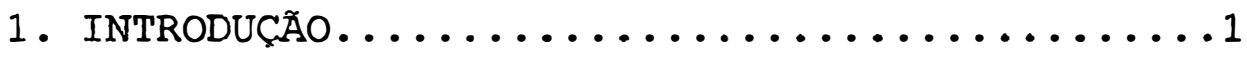

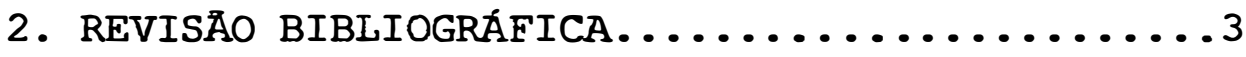

2.1. Sistemas de manejo do solo..............

2.2. Biomassa microbiana do solo..........8

2.3. Enzimas no solo..................12

2.3.1.Aspectos gerais...............12

2.3.2.Atividade de desidrigenase.......14

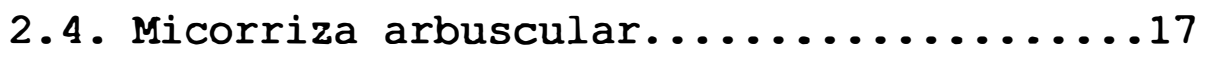

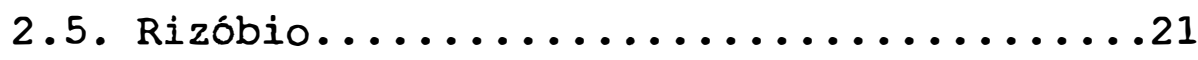

3. MATERIAIS E MÉTODOS...................... . . 24

3.1. Caracterização edafo-climática da área..24

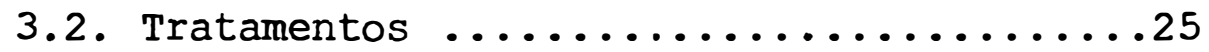

3.3. Delineamento experimental...........26

3.4. Instalação. e condução do experimento....................26

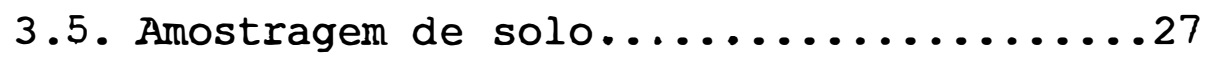

3.6. Preparo das amostras de solo..........28

3.7. Análises do solo..................29

3.7.1. Umidade atual..............29

3.7.2. N-amoniacal e $\mathrm{N}$ (nitrato+nitrito) 30

3.7.3. Determinação de $\mathrm{pH}, \mathrm{P}, \mathrm{Ca}, \mathrm{Mg}$ e

S.................................. 
3.8. Determinação de microrganismos do solo..31 3.8.1. Biomassa microbiana............31

3.8.2. Atividade de desidrogenase......32

3.8.3. Bactérias e fungos.............33

3.8.4. Contagem e identificação de esporos....................... 34

3.9. Análises de plantas...............34

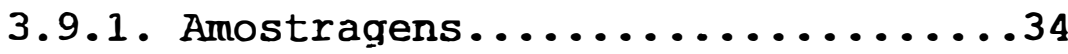

3.9.2. Análise química da parte aérea...34

3.9.3. Amostragens de raizes..........35

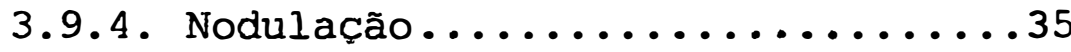

3.9.5. Avaliação da produção.........35

4. RESULTADOS E DISCUSSÃo....................

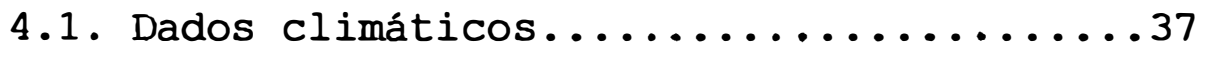

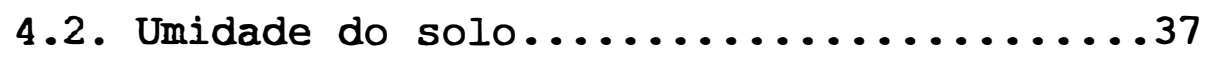

4.3. Fertilidade do solo...............40

4.4. Quantificação de fungos e bactérias....47

4.5. Biomassa microbiana do solo..........48

4.6. Atividade de desidrogenase do solo.....55

4.7. Micorriza...................60 60

4.7.1. Porcentagem de colonização endomicorriza.............60

4.7 .2 . Fungos MA...............63

4.8. Rizóbio....................68

4.9. Teores de nutrientes da parte aerea....70 4.10.Produção da soja e aveia-preta........74

5. CONCLUSOES....................... 76

REFERENCIAS BIBLIOGRAFICAS...........77 
AVALIAÇÃO DE PARÂMETROS MICROBIOLÓGICOS EM DIFERENTES SISTEMAS DE MANEJO DO SOLO

Autora: SILVANA APARECIDA PAVAN FERNANDES

Orientadora: Profa.Dra. ELKE J. B. NOGUEIRA CARDOSO

RESUMO

O objetivo do presente trabalho foi determinar o efeito do sistema de preparo do solo e rotação de culturas sobre alguns parâmetros microbiológicos do solo. Para isto foram utilizados amostras retiradas de parcelas de um experimento de campo instalado em latossolo roxo distrófico, as quais vem recebendo diferentes tipos de manejo há mais de dez anos. Para esse estudo, as amostragens foram feitas de julho/92 até janeiro/94. Utilizou-se o delineamento em blocos casualizaos com quatro tratamentos (plantio direto com soja contínua e plantio direto com soja em rotação com milho; plantio convencional com soja contínua e plantio convencional com soja em rotação com milho). A amostragem de solo foi realizada em três profundidades $(0-5,5-10$ e 10-20 cm) e em oito épocas diferentes, respectivamente: 10/07/92 (inicio do experimento); 06/01/93 (semeadura da soja); 29/03/93 (florescimento da soja); 06/05/93 (colheita da soja); 14/05/93 (semeadura da aveia); 24/07/93 (florescimento da aveia); 03/10/93 (colheita da aveia) e 05/01/94 (semeadura da soja). Os seguintes parâmetros foram avaliados: biomassa microbiana, atividade de 
desidrogenase, número de nódulos em soja infectada com Bradyrhizobiun, número de esporos de fungos micorrizicos arbusculares, porcentagem de fungo micorrizico arbuscular e número de fungos e bactérias heterotróficas aeróbicas.

Observou-se que o teor de umidade no solo foi influenciado pela época de amostragem não tendo sido afetada pelo manejo do solo. No plantio direto verificaram-se maiores valores de: biomassa microbiana, atividade de desidrogenase e teores de matéria orgânica e fósforo, principalmente nos $5 \mathrm{~cm}$ superficiais do solo. Todos estes valores, entretanto, foram decrescendo com 0 aumento da profundidade. Tanto a biomassa como a atividade da desidrogenase foram influenciadas pelos fatores manejo do solo, profundidade e época; sendo maiores nas épocas mais quentes e pluviosas. Houve também uma tendência das áreas sob plantio direto apresentar os maiores valores de contagem de fungos e bactérias. Obteve-se uma correlação significativa entre as três variantes do método de biomassa e verificou-se que seria possivel estimá-la através da atividade de desidrogenase. A nodulação e a micorrização em soja foram baixas, embora as causas permaneçam desconhecidas. Em contraposição, a porcentagem de micorrização na cultura de aveia foi relativamente alta. O número de esporos de fungos micorrizicos arbuscular (MA) foi relativamente baixo e houve a predominância da espécie scuttelospora gregaria para todos os tratamentos e em todas as épocas amostradas. Os teores de nitrogênio nas culturas de soja e aveia foram superiores para o solo sob PC, não havendo diferenças marcantes para os demais nutrientes. A produção da soja e da aveia não foram afetadas pelos diferentes sistemas de manejo do solo. 
EVALUATION OF MICROBIOLOGICAL PARAMETERS IN THE DIFFERENT SOIL MANAGEMENT SYSTEMS

Author: SILVANA APARECIDA PAVAN FERNANDES

Adviser: Profa.Dra. ELKE J. B. NOGUEIRA CARDOSO

SUMMARY

The aim of this study was to determine the effect of different soil management practices on several soil microbiological parameters. Samples from plots of a field experiment on typic harplortox, which have been cultivated under different management systems for more than ten years, were used. The experimental design was in random blocks with four treatments of soil management (tillage soybean-corn rotation, tillage soybean continuously, no-tillage soybean-corn rotation and no-tillage soybean continuously) and two repetitions. Sampling at 3 depths were performed from july, 1992 to January, 1994, at eight time points, respectively: 7/10/92 (first sampling); 1/6/93 (soybean sowing); $3 / 29 / 93$ (soybean blooming); $5 / 6 / 93$ (soybean harvesting); 5/14/93 (oat sowing); 7/24/93 (oat blooming); 10/3/93 (oat harvesting) and 1/5/94 (soybean sowing). The following parameters were analyzed: microbial biomass, dehydrogenase activity, number of nodules in soybean infected with Bradyrhizobuin, number of arbuscular mycorrhizal fungal spores, percentage of 
root colonization by arbuscular fungi and number of heterotrophic aerobic fungi and bacteria.

The soil humidity was affected during the time course but not by the soil management system. The highest values of microbial biomass, dehydrogenase activity, organic matter and phosphorus concentration were observed in no-tillage, mainly in the upper $5 \mathrm{~cm}$ of the soil. These values decreased with increasing depth. Biomassas as well as dehydrogenase activity were affected by soil management, soil depth and time of sampling. The highest values were obtained during the hottest and rainy periods. In soil with no-tillage the number of viable propagules of fungi and bacteria were higher. A significative correlation was obtained between the three different biomass determination methods and dehydrogenase activity. Thus, dehydrogenase activity can be used to estimate microbial biomass in the soil. The level of infection by mycorrhizal fungi and nodulation in soybean were low. However, the mycorrhizal infection in oat was somewhat higher. The causes for such differences are unknown. Even though the number of arbuscular mycorrhizal fungal spores was low, Scuttelospora gregaria species were predominant in all treatments and time points. Nitrogen concentration in leaves of soybean and oat were higher in soil with tillage system than in no-tillage. No differences were detected for other nutrients. Soybean and oat yields were not affected by different systems of soil management. 


\section{INTRODUÇÃO}

Uma atividade agrícola bastante expressiva em termos economicos, no Brasil é o cultivo da soja. Segundo ROESSING (1994) a produção mundial de soja em 1992/1993 foi estimada em 116,7 milhões de toneladas e a produção brasileira foi de 22,89 milhões de toneladas, para uma área cultivada de mais de 10 milhões de ha. Sendo a concorrência externa bastante significativa, somente $o$ uso de tecnologia avançada conseguirá manter a competitividade brasileira no setor.

No Brasil estão sendo estudadas diversas tecnologias para $\circ$ aumento da produtividade. Atualmente tem sido muito utilizado o plantio direto, que é um sistema conservacionista e de preparo de solo, com resultado principal na redução da erosão em até $85 \%$ quando comparado ao sistema convencional, o que seria suficiente para justificar a sua aplicação, pois nenhum outro fenômeno do solo é mais destrutivo em âmbito mundial do que a erosão, a qual resulta também em elevadas perdas de nutrientes do solo. o plantio direto está sendo utilizado para a expansão de novas fronteiras agricolas, principalmente no cerrado, com a implantação da soja.

o plantio direto, por ser um processo de semeadura em solo não revolvido, no qual a mobilização 
é efetuada apenas na linha de plantio, mantendo-se os restos de cultura anterior na superfície, protege 0 solo contra a chuva e permite maior infiltração de água. Esse sistema de preparo do solo, associado à rotação de culturas, pode influir nas características físicas, químicas e biológicas do solo; a prática dos diferentes sistemas de preparo do solo promove modificações diversas na microbiota através de seus efeitos diretos e indiretos sobre os fatores relacionados ao solo e às plantas (MUZILLI, 1983).

o solo é um sistema muito dinâmico, onde fatores de natureza física, química e biológica interagem continuamente. As transformações microbianas, por conta das diferentes populações que neles ocorrem, assim como suas diferentes reações químicas, podem ser alteradas sempre que esse ecossistema sofra algum tipo de interferência. Na utilização de diferentes tipos de manejo do solo devem ser esperadas modificações qualitativas e quantitativas na constituição desse solo.

No Brasil, a maioria das pesquisas relacionadas com diferentes sistemas de manejo do solo dão ênfase ao estudo de parâmetros físicos e químicos, existindo pouquíssimos trabalhos envolvendo aspectos microbiológicos do solo. Nesse intuito, o objetivo do presente trabalho foi avaliar o efeito do sistema de preparo de solo e rotação de cultura sobre alguns parâmetros microbiológicos do solo. 


\section{REVISÃO BIBLIOGRÁFICA}

\subsection{Sistemas de manejo do solo}

Nos últimos anos, tem-se procurado desenvolver sistemas de manejo do solo mais adequados às condições edafo-climáticas de distintas regiões. Alguns dos sistemas de manejo de solo que vêm sendo difundidos na agricultura, entretanto, têm como objetivo principal o controle da erosão, evitando a degradação dos solos. Entre estes sistemas está o plantio direto, que tem características contrastantes em relação aos sistemas tradicionais. No sistema de plantio direto, não há preparo prévio do solo na área de cultivo, sendo o plantio feito sobre a palha deixada pelas culturas anteriores e pelas ervas daninhas dessecadas com herbicidas. Pode-se definir plantio direto como a semeadura com revolvimento do solo apenas no sulco ou cova onde se depositam a semente e o fertilizante, permanecendo o restante da superfície sem mobilização, em contraste com outros sistemas, em que a mobilização é feita em toda a área. Esse sistema elimina, portanto, as operações de aração, gradagem e outros métodos convencionais de preparo do solo, e as ervas daninhas são controladas com herbicidas, em aplicações antes e/ou após a semeadura ( MUZILLI, 1983 
e DE MARIA \& CASTRO, 1993). Segundo LOMBARDI NETO (1990) o plantio direto reduz as perdas de solo em 85\% quando comparado ao sistema convencional; resultados semelhantes foram obtidos por BENATTI Jr. et al. (1977) e CASTRO et al. (1986ab).

A quantidade de residuos vegetais que permanece no terreno sob plantio direto é o mesmo que sob plantio convencional. No entanto, no primeiro caso, esses resíduos ficam à superfície, e no segundo, são enterrados. Esta diferença provoca alterações na taxa de decomposição do material vegetal. A incorporação dos resíduos orgânicos favorece 0 arejamento 0 que, concomitantemente com a introdução dos resíduos vegetais, acelera a atividade microbiana e, consequentemente, sua decomposição (SILVA \& VIDOR 1984). Por essas razões, $O$ teor de matéria orgânica no solo sob plantio direto é, normalmente, superior ao que se verifica en preparo convencional (aração mais 2 gradagens, com incorporação de resíduos vegetais), concentrando-se na camada superficial CANNEL \& FINNEY, 1979 e MUZILLI, 1983).

MUZILLI (1983) encontrou aumento significativo no teor de matéria orgânica na camada superficial em dois solos do Paraná, após 5 anos sob plantio direto; nessa mesma área, com 3 anos de experimento, o solo sob plantio direto apresentou teor de matéria orgânica semelhante ao plantio convencional (MOZILLI, 1981). CASTRO et al.(1987) também não observaram diferenças significativas no teor de matéria orgânica entre os sistemas de plantio direto e convencional em nenhum dos solos estudados em diferentes profundidades, após três anos de experimentação. Além do solos sob plantio direto por muitos anos apresentarem teores maiores de matéria 
orgânica nas camadas superficiais, em relação aos arados, eles apresentam também níveis mais elevados de carbono e nitrogênio CANNEL \& FINNEY (1979), BLEVIS et al. (1983) e DE MARIA \& CASTRO (1993).

Solos sob plantio direto, apresentam também maior umidade, menor superfície de contato solonutriente, maior aeração, menor variação de temperatura, diminuição do $\mathrm{pH}$ dosolo na camada superficial e maior capilaridade, afetando a dinâmica dos nutrientes (MUZILII, 1983 e CASTRO et al., 1987). Essa acidificação da camada superficial pode ser devida à adubação nitrogenada que, permanecendo nas camadas mais superficiais, leva a uma queda no $\mathrm{pH}$. No sistema de plantio direto a zona de acidificação ocorre principalmente nos primeiros $5 \mathrm{~cm}$, podendo chegar até à profundidade de $20 \mathrm{~cm}$, mas em menor proporção, sendo que a calagem superficial resolve o problema da acidez (THOMAS 1980).

THOMAS (1980) verificou que reduções do teor de nitrogênio foram mais acentuadas em milho sob plantio direto, decorrentes do movimento descendente da água, e consequente lixiviação de nitratos, já que a não movimentação do solo, no sistema de plantio direto, evita a quebra da capilaridade. Por outro lado, haveria menor taxa de mineralização da matéria orgânica e menor dispionibilidade de nitrogênio em sitema de plantio direto; resultados semelhantes foram obtidos por MUZILII, 1983. DE MARIA \& CASTRO (1993) utilizando - mesmo solo do presente estudo, observaram que solos sob plantio direto apresentam maiores teores de fósforo comparados com solos escarificados e solos sob plantio convencional.

MUZILLI (1983) também verificou acúmulo superficial de fósforo em condições de plantio direto 
após quatro anos de cultivo, sobretudo nos $5-10 \mathrm{~cm}$ superficiais o que se explica pela baixa mobilidade e solubilidade desse nutriente, sobretudo em solos contendo altos teores de argila e sesquióxidos de $\mathrm{Fe}$ e Al, como é ocaso do solo em estudo (THOMAS, 1980, RAIJ, 1991 e RAIJ, 1983 ). DE MARIA \& CSTRAO (1993) e MUZILLI (1983) constataram um expressivo aumento nos teores de fósforo na camada superficial do solo em plantio direto.

Em latosslo vermelho textura argilosa, o teor de potássio trocável na camada de 0-5 cm apresentou aumento significativo sob plantio direto, comparando com solo sob plantio convencional; já no caso do latossolo vermelho textura média, essas diferenças entre os sistemas de plantio direto e convencional não foram observadas (CASTRO et al. 1987). THOMAS (1980) observou que há muito pouco efeito do preparo do solo nas quantidades de $K$ disponível. $O \mathrm{~K}$ aplicado na superfície do solo, em sistema de plantio direto, tem sido encontrado distribuido no perfil do solo da mesma maneira que o $\mathrm{K}$ aplicado na superficie do solo e incorporado em sistema de preparo convencional. Resultados semelhantes foram obtidos por DE MARIA \& CASTRO (1993). Em contrastre, outros autores verificaram um aumento na concentração de $K$ no solo sob preparo reduzido (CENTURION \& DEMATTÊ, 1985 e ROBBINS \& VOSS, 1991). Desta forma, o tipo de solo, o teor e o tipo de mineral de argila presentes e as condições de drenagem podem determinar se haverá ou não diferenças entre os sistemas de manejo quanto ao teor de $K$ no solo (MUZILLI 1983).

Em relação ao cálcio e magnésio, CASTRo et al. (1987) não observaram diferenças entre os diferentes sistemas de preparo de solo. 
No caso de micronutrientes, MALHER et al. (1982) constataram diferenças significativas entre solos sob diferentes sistemas de preparo de solo na distribuição de $\mathrm{Zn}, \mathrm{Cu}, \mathrm{Fe}$ e Mn. BLEVINS et al. (1977) observaram que os teores de Mn trocável eram maiores em área sob plantio direto que no plantio convencional, sendo que os valores mais elevados de $\mathrm{Mn}$ coincidiram com os de $\mathrm{pH}$ mais baixos; resultados semelhantes foram obtidos por FOLLET \& PETERSON (1988) para $\mathrm{Zn}, \mathrm{Cu}$, Fe e Mn. HARGOVE et al. (1982) não observaram diferenças significativas em relação ao $\mathrm{Cu}$ em áreas sob plantio direto e convencional, porém CASTRO et al. (1992) constataram que $\circ \mathrm{Cu}$ apresentou teores significativamente mais elevados sob plantio direto, especialmente nas camadas superficiais do solo.

Comparando o sistema de plantio direto com plantio convencional, observa-se que 0 plantio direto provoca um aumento significativo da densidade do solo na camada mais superficial, por não sofrer revolvimento periódico. Em solos sob plantio convencional, por outro lado, pode ocorrer a formação de uma camada mais adensada a $10-20 \mathrm{~cm}$ de profundidade (VIEIRA \& MUZILLI, 1982; MUZILLI, 1983 e SIDIRAS et al., 1984). Em plantio direto, verifica-se maior estabilidade dos agregados do solo até uma profundidade de $15 \mathrm{~cm}$ (VIEIRA \& MUZILLI, 1982).

A cobertura morta, a temperatura e a umidade do solo são fatores interligados e, quando manejados adequadamente, podem propiciar beneficios à produção agrícola. MUZILLI (1981) afirma que a cobertura morta que se acumula sobre o solo no plantio direto contribui para o armazenamento de água através da formação de uma camada isolante que impede maior evaporação da água. A cobertura morta contribui ainda 
indiretamente para maior conservação da água no solo e no controle de ervas daninhas, as quais iriam consumir grande parte de água por transpiração.

Em diferentes condições ambientais, solos sob plantio direto contém de 36 a 45\% mais água do que solos sob preparo convencional, sendo essa diferença mais pronunciada na camada superficial do solo (BLEVINS et al., 1971 e SIDIRAS \& PAVAN, 1983). Essa maior retenção da água em solos sob plantio direto só ocorre quando $\circ$ teor de matéri orgânica atinge niveis mais elevados (SIDIRAS et al., 1982 e CASTRO, 1987); afetando as características físicas e químicas do solo.

Um aumento de $34.4 \%$ no rendimento da soja foi observado em solo sob plantio direto, comparada com preparo convencional. Enquanto que o sistema de rotação de culturas aumentou 19.2\% o rendimento da soja em relação ao monocultivo (CALEGARI et al., 1994 e TORRES et al., 1994).

\subsection{Biomassa microbiana do solo}

A biomassa microbiana do solo, definida por JENKINSON \& LADD (1981) como a parte viva da matéria orgânica do solo, excluídas as raízes e animais menores, apresenta papel fundamental dentro dos ciclos biogeoquímicos dos elementos de interesse para a produtividade agrícola e para a ecologia. Sua quantificação é, portanto, indispensável no estudo da ciclagem de certos elementos (carbono, nitrogênio, fósforo) e na avaliação do estado ecológico, estando seu nível e sua atividade diretamente relacionados com a fertilidade e equilíbrio do solo, tanto em 
ecossistemas naturais como nos agrossistemas. A biomassa constitui um meio de transformação para todos os materiais orgânicos do solo e atua como reservatório de nutrientes vegetais. O reconhecimento da importância dos microrganismos do solo tem levado a um aumento no interesse em se medir os nutrientes contidos em suas biomassas, cuja estimativa fornece dados úteis sobre mudanças nas propriedades biológicas do solo decorrentes de seu uso (MARUMOTO et al., 1982ab; GRISI, 1984; GRISI \& GRAY, 1986; VANCE \& JENKINSON, (1987b). Com o crescente aumento do interesse em se estudar a biomassa microbiana dos solos, vários métodos foram desenvolvidos. Contudo, a confiabilidade destes métodos tem sido amplamente questionada, uma vez que a estimativa da biomassa pode ser afetada pelas condições edafo-climáticas.

Os métodos mais utilizados na

quantificação da biomassa microbiana do solo são o da fumigação-incubação (F-I) (JENKINSON \& POWLSON, 1976), - da taxa de respiração em resposta a adição de glicose (ANDERSON \& DOMSCH, 1978); O da determinação de ATP (OADES \& JENKINSON, 1979) e o da fumigação-extração (FE) (VANCE \& JENKINSON, 1987). O método F-I é amplamente utilizado devido a grande facilidade de execução e por permitir uma estimativa direta da biomassa microbiana. Porém essa técnica não é eficiente em solos com $\mathrm{pH}$ inferior a 4,5 nas regiões de clima temperado. $O$ método $F-E$ vem sendo utilizado, principalmente para suprir a limitação do método $\mathrm{F}-\mathrm{I}$ para os solos ácidos, e, em geral, apresenta boa correlação com o método F-I (GERALDES, 1993 encontrou $r=0,93 * \star$; PFENNING et al., 1992 encontraram $r=0,95 * \star$ ). Os demais métodos requerem recursos técnicos e financeiros mais elevados (JENKINSON\& LADD, 1981; 
SAMPAIO \& SALCEDO, 1982; GRISI \& GRAY, 1986 e GRISI \& GRAY, 1986)e são pouco utilizados.

A calagem e a adubação favorecem 0 desenvolvimento microbiano de forma direta, pelo aumento do $\mathrm{pH}$ e da disponibilidade de nutrientes, e, indiretamente, pela maior produção vegetal, que acarreta aumento da atividade rizosférica e dos resíduos adicionados ao solo ( DORAN, 1980; ELYNCH \& PANTING, 1980; NUERNBERG et al., 1984; SILVA \& VIDOR, 1984).

A interação entre o manejo do solo e da cobertura vegetal e as variações climáticas durante as diferentes épocas do ano, principalmente em regiões sub-tropicais, onde as estações são bem definidas, faz com que ocorram flutuações sazonais no desenvolvimento microbiano. Essa é maior nas camadas superficiais do solo, onde existem as maiores oscilações de umidade e temperatura (CAMPBEL \& BIEDERBERCK, 1976 e CAMPBEL, 1982). Esses efeitos são mais pronunciados em solos cultivados com espécies anuais do que naqueles com pastagens perenes (NUERNBERG et al., 1984), devido à maior variação na cobertura vegetal e aporte de nutrientes. Porém, as pastagens permanentes também estão sujeitas a flutuações, conforme foi observado para biomassa microbiana em outros estudos (ROSS, 1980).

SILVA \& VIDOR (1984) observaram que diferentes sistemas de preparo do solo não alteram sensivelmente a comunidade microbiana avaliada por contagem em placas, a qual foi, no entanto, estimulada pelo cultivo de pastagens e rotação de culturas, enquanto a queimada da palha de trigo tendeu a reduzila. FIALHO et al. (1991) avaliaram a atividade biológica (através do despreendimento de $\mathrm{CO}_{2}$ ), que 
decresceu com a profundidade das amostras no perfil, independente do tipo de cobertura vegetal. Essa redução na atividade biológica está relacionada com o decréscimo do $\mathrm{C}$ orgânico e a atividade biológica pode ter sido favorecida nas camadas superficiais pela maior quantidade de nutrientes. A biomassa microbiana depende primordialmente da disponibilidade de substrato orgânico, além de fatores ambientais como temperatura, umidade e textura do solo (PFENNING et al., 1992).

CATTELAN \& VIDOR (1990ab) observaram que a profundidade exerceu qrande efeito sobre os microrganismos. As flutuações na biomassa e comunidade microbiana foram acentuadas na superficie $(0-5 \mathrm{~cm})$, colaborando para isso as variações climáticas, manejo do solo e os tipos de cultura. As comunidade fúngicas e de actinomicetos não foram muito afetadas pelos diferentes sistemas, sendo a matéria orgânica e a fertilidade do solo os fatores que mais estimularam a comunidade microbiana.

Segundo CAMPBELI (1982) as maiores comunidades de microrganismos são verificadas no período imediatamente após as colheitas, devido à maior disponibilidade de material orgânico. A incorporação de residuos orgânicos também pode favorecer os microrganismos por promover melhoria nas caracteristicas físicas do solo, como retenção de umidade e manutenção da temperatura e aeração (DORAN 1980). NUERNBERG et al. (1984) verificaram que a atividade microbiana foi dependente das culturas e do tipo de adubação.

CARTER (1986) e CARTER \& RENNIE (1992) encontraram que $\bigcirc$ carbono e o nitrogênio da biomassa microbiana diminuem com a profundidade e que o sistema de preparo de solo reduzido apresentou maior biomassa, 
sendo esta sensível quanto ao manejo do solo e tipos culturais. PAVAN (1991) constatou que o tipo de cultura (citros, soja e milho) e a época de amostragem influem na biomassa microbiana do solo e que esta diminui com a profundidade.

CATTELAN \& BORKET (1994); CATTELAN \& GAUDÊNCIO (1994) E CATTELAN \& TORRES (1994) observaram que a biomassa microbiana teve correlação positiva com os teores de $\mathrm{Ca}, \mathrm{Mg}, \mathrm{C}$ orgânico, $\mathrm{P}$ do solo e também com o indice de $\mathrm{pH}$, e que o sistema de preparo do solo e época de amostragem influiram na biomassa microbiana. DORAN, (1980) observou acúmulo de biomassa microbiana na superfície do solo sob plantio direto em relação ao convencional.

\subsection{Enzimas no solo}

\subsubsection{Aspectos gerais}

A enzimologia do solo tem-se desenvolvido consideravelmente, tendo em vista sua potencialidade em processos bioquímicos especificos (MELO, 1988). As enzimas microbianas ocupam um papel crucial na ciclagem de nutrientes, realizando uma variedade de reações de oxidação e redução para conversão do material orgânico necessário para a manutenção do equilíbrio de um ecossistema. A maioria dos trabalhos tem sido desenvolvidos em ecossistemas de clima temperado, conhecendo-se muito pouco sobre enzimologia de solos de sistemas tropicais (PALMA \& TAUK, 1982).

No geral, assume-se que as enzimas do solo tem origem microbiana (LADD, 1978), mas pode 
existir também uma contribuição de animais e plantas (BURNS, 1978 ; SKUJINS, 1978 e BURNS, 1982).

A vegetação pode afetar direta ou indiretamente o conteúdo de enzimas dos solos (ROSS, 1982). Raízes de plantas podem excretar enzimas extracelulares ( SKUJINS, 1978 e DICK \& TABATABAI, 1986). De modo geral, na rizosfera, a atividade enzimática é mais elevada, todavia não se sabe ao certo se isto se deve ao maior número de microrganismos ou a excreções radiculares, ou ainda a ambos, o que parece ser mais provável (SKUJINS, 1978; MELO et al., 1989; e CATELLANO \& DICK 1991).

No geral, o que se tem feito em termos de enzimologia de solo é a determinação da atividade enzimática e dos fatores que sobre ela podem influir. Para tal, amostras de solo são incubadas na presença de substrato específico e de um inibidor da atividade microbiana, avaliando-se em seguida o desaparecimento do substrato ou aparecimento do produto (TABATABAI, 1982 e MELO, 1988 ).

Para a esterilização ou inibição dos microrganismos do solo durante o periodo de incubação, tem se feito uso de agentes químicos (tolueno, óxido de etileno, fenol, acetona, timol, clorofórmio,etc) e agentes físicos (calor, radiações ionizantes) (SKUJINS, 1973 e MELO, 1988).

Entre os fatores que influem na determinação da atividade de enzimas do solo estão o armazenamento e o preparo das amostras, já que o manuseio e a secagem ao ar podem alterar o número de microrganismos, atividade enzimática, $\mathrm{pH}$, temperatura, tempo de incubação e concentração de substrato (TABATABAI, 1982 e MELO, 1988). 
Existe grande interesse em desenvolver um método baseado na atividade enzimática do solo que possa ser usado como índice para avaliar a fertilidade do solo e/ou sua atividade biológica para fins agrícolas (SKUJINS, 1978; DICK , 1988ab e MARTENS et al., 1992). De um modo geral, tem sido observado que a atividade enzimática do solo é influenciada pelo sistema de preparo, rotação de cultura, resíduos culturais, aumentando sua atividade a longo prazo com a rotação de cultura e manejo do solo, principalmente para desidrogenase, urease, protease, fosfatase, amilase e arilsulfatase (DORAN, 1980; DICK, 1984; BOLTON et al. 1985; DICK, 1988 b; PAVAN, 1991 e MARTENS et al. 1992). Observou-se que a maioria das enzimas do solo parece acompanhar a distribuição da matéria orgânica, isto é, aumentam a atividade com o aumento da matéria orgânica (BURNS, 1982; SKUJINS, 1976 e BURNS, 1978).

\subsubsection{Atividade de desidrogenase}

Têm sido estudadas aproximadamente 50-60 enzimas no solo (LADD, 1978 e MELO, 1988). As enzimas de solo mais estudadas são as oxidorredutases, as transferases e as hidrolases.

A oxidorredutase desidrogenase tem sido estudada em solo, particularmente por causa do seu papel na oxidação da matéria orgânica, quando são transferidos eletrons dos substratos para aceptores. A atividade de desidrogenase depende da atividade metabólica total da comunidade microbiana viável, e existe somente em células intactas (SKUJINS, 1976). 
Algumas hidrolases e transferases tem sido exaustivamente estudadas por causa de seus papeis na decomposição de vários substratos orgânicos, sendo importantes no ciclagem de nutrientes (C, N, $P, S$ ) e formação do húmus.

.. STEVENSON (1959 e 1962) estudou a redução de cloreto de 2,3,5,-trifeniltetrazólio (TTC) a trifenilformazana (TTF) como medida da atividade da desidrogenase in situ. Investigações preliminares sugeriram que a formação de formazana pode ser usada como um índice de respiração endógena no solo. STEVENSON (1959) observou correlação significativa entre a atividade de desidrogenase e a taxa de oxigênio consumida em diferentes solos e uma relação direta foi observada entre a atividade da desidrogenase e o número de bactérias aeróbicas.

Alguns estudos mostraram haver correlação entre a atividade microbiana ou biomassa microbiana e algumas enzimas, como a desidrogenase, a protease, a celulase, a fosfatase e a urease (NANNIPIERI, 1978; ROSS \& CAIRNS, 1982 e FRANKESBERGER \& DICK, 1983). FRANKENBERGER \& DICK, 1983) encontraram correlação entre a respiração microbiana e a desidrogenase $\left(r=0,83^{* *}\right)$; CASIDA Jr. et al., 1964 verificou correlação entre a atividade de desidrogenase e 0 número de microrganismos. A correlação positiva entre a atividade de desidrogenase e a liberação de $\mathrm{CO}_{2}$ tem sido relatada também por outros autores ( SKUJINS, 1973; CASIDA Jr., 1977 e DICK et al., 1988ab).

STEFANIC (1984) propôs um índice biológico de fertilidade do solo (BIF), calculado através da atividade de desidrogenase mais a atividade da catalase: $\mathrm{BIF}=1 / 2(\mathrm{DHG}+\mathrm{KCA})$ onde, $\mathrm{DGH}=$ atividade 
de desidrogenase, $\mathrm{CA}=$ atividade da catalase e $\mathrm{K}=$ coeficiente de proporcionalidade.

Comparando-se rotação de cultura com sistema de monocultura, tem-se observado que a atividade enzimática dos solos é sensivel ao efeito associado com sistemas de rotação de cultura (DICK, 1984; BOLTON et al. 1985 e DICK et al., 1988a). DORAN, (1980) e DICK, (1984) verificaram que o plantio direto produz menos distúrbio no solo do que o sistema de plantio convencional e tem aumentado $\circ$ nível de atividade enzimática na superficie do solo (profundidade < $10 \mathrm{~cm}$ ). DORAN (1980) relatou que a atividade de desidrogenase aumentou de 10 para $190 \%$ na profundidade $0-7,5 \mathrm{~cm}$ em sistema de plantio direto em comparação ao convencional; uma resposta similar foi obtida para atividade da fosfatase. Em solos sob plantio direto que inclui uma leguminosa a atividade enzimática do solo é maior do que em solos sob sistema convencional (BOLTON et al. 1985).

o acúmulo de nutrientes orgânicos e inorgânicos na superfície do solo sob plantio direto cria um ambiente favorável ao crescimento microbiano e sua atividade metabólica (DORAN, 1980 e DICK et al., 1983). DORAN (1980) constatou diferenças na comunidade e atividade de desidrogenase em diferentes sistemas de preparo de solo (plantio direto e convencional), apresentando $\circ$ plantio direto maior atividade de enzima. Provavelmente, o conteúdo de água no solo, temperatura, aeração e substrato residual associado ao sistema de preparo do solo tenha influido nos tipos de microrganismos que predominarame suas atividades. 


\subsection{Micorriza arbuscular}

A grande maioria das plantas, incluindo as de maior interesse econômico, formam em suas raizes associações simbióticas com fungos endomicorrízicos arbusculares, os quais influenciam a absorção de nutrientes do solo ( HAYMAN, 1975; MOSSE, 1979; EZETA \& CARVALHO 1982; LOPES et al. 1983a; CARDOSO, 1985 e CARDOSO, 1986). É grande o interesse nesses fungos como incrementadores de crescimento de plantas, graças à sua capacidade de absorção de fosfatos e outros nutrientes como $\mathrm{Cu}, \mathrm{Zn}, \mathrm{Mg}, \mathrm{S}, \mathrm{K}$ e $\mathrm{N}$, possibilitando a diminuição do uso de fertilizantes (CLARKE \& MOSSE 1981; LOPES et al. 1983a; ZAMBOLIM \& SIQUEIRA, 1985; FERNANDES et al. 1987; SIQUEIRA \& FRANCO, 1988 e MINHONI et al., 1993).

A densidade e a diversidade de fungos arbusculares, bem como 0 estabelecimento das associações endomicorrízicas são condicionadas por vários fatores bióticos e abióticos, intrínsecos a determinados ecossistemas, tais como: tipo de solo, disponibilidade de nutrientes, pH , umidade, aeração - temperatura e luminosidade e presença de outros microrganismos que podem atuar como micófagos, parasitas, competidores (MOSSE et al., 1981; ZAMBOLIM \& SIQUEIRA, 1985; ANTUNES et al., 1988; SIQUEIRA \& FRANCO, 1988; SILVEIRA, 1992).

A micorrização aumenta a nodulação e a fixação biológica do nitrogênio (FBN), e esses efeitos resultam, principalmente, da melhoria do estado nutricional, do favorecimento no crescimento e de modificações fisiológicas. Esses efeitos benéficos se manifestam também na eficiência dos nódulos e na 
produção agrícola (SAITO et al. 1983; CARDOSO, 1985 e PAULA \& SIQUEIRA, 1987a).

o manejo das culturas, a rotação e o emprego de plantas hospedeiras e não-hospedeiras podem afetar a densidade de propágulos do fungo, bem como a capacidade infectiva do solo. 0 emprego de fertilizantes químicos e orgânicos afeta a comunidade de fungos micorrizicos no solo, enquanto que rotações de cultura podem alterar a quantidade e qualidade de esporos em função da seleção existente para diferentes hospedeiras, De uma maneira geral, vários autores mencionam que na transição de vegetação nativa para monocultura houve diminuição na diversidade dos fungos levando à seleção das combinações solo-hospedeiro-fungo MA mais eficientes (CRUSH, 1974; SCHENCK \& KINLOCH, 1976 e MOSSE et al., 1981 ).

Os efeitos de fungicidas, inseticidas e herbicidas, sobre os fungos MA têm recebido relativamente pouca atenção por parte dos pesquisadores, e pouco se sabe sobre seus mecanismos de ação. Segundo MENGE (1982), fungicidas sistêmicos e não-sistêmicos podem atuar de forma positiva ou negativa ou, mesmo, não ter efeito sobre a colonização radicular ou produção de esporos; os fungicidas nãosistêmicos podem agir primariamente na germinação dos esporos e no processo de infecção, sendo menos prejudiciais à simbiose em si do que os sistêmicos. Alguns fungicidas sistêmicos podem reduzir ou inibir a colonização das raízes, tornando-se extremamente prejudiciais em plantas com alta dependência micorrízica.

É importante o conhecimento da ocorrência e distribuição de fungos MA no Brasil, para melhor compreensão dos aspectos ecológicos entre $O$ fungo e a 
planta nos agro e ecossistemas existentes, bem como obter subsídios para posterior utilização desses fungos na agricultura. Com esse intuito, foram realizados levantamentos de esporos MA em diversas regiões do país (THOMAZINI \& CASA GRANDE 1981; BONONI \& FRUFEN 1983; SAITO et al. 1983; SANO, 1984; TRUFEM \& BONONI 1985; BONONI et al., 1988; SIQUEIRA et al. 1989; TRUFEM et al. 1989; MAIA \& TRUFEM 1990; OLIVEIRA et al. 1990; TRUFEM, 1990; e COSTA \& BONONI 1991).

A literatura disponivel sobre a

distribuição geral de fungos MA, menciona que as espécies de Scutellospora e Acaulospora são as espécies mais comuns em solos tropicais ( MOSSE et al. 1981; LOPES et al. 1983b e TRUFEM \& BONONI 1985), em contraposição aos solos de regiões temperadas, onde predominam as espécies de Glomus (MOSSE et al., 1981).

Em levantamento de fungos $M A$ conduzidos no Brasil, predominou o gênero Acaulospora para regiões de Minas Gerais e Pernambuco, principalmente as espécies Acaulospora scrobiculata e Acaulospora morrowae (FERNANDES et al., 1987; SIQUEIRA et al., 1989; MAIA \& TRUFEM, 1990 e OLIVEIRA et al. 1990). O gênero Acaulospora também predominou em diversas outras regiões do país (FERRAZ, 1979 e LOPES et al., 1983b).

$\mathrm{Na}$ regiáo de Mogi-Guaçu/SP, BONONI \& TRUFEM (1983) verificaram a predominância de esporos de Gigaspora heterogama, Gigaspora nigra e Gigaspora gilmorei e em levantamento na cultura de amendoim, Mogi-Guaçú, predominaram as espécies Glomus macrocarpum e Glomus fecundisporum. Observa-se que várias espécies de Gigaspora foram reclassificadas como scutellospora de acordo com WALKER \& SANDERS, 1986. Em roseira, no Estado de São Paulo verificaram-se predominância de Glomus e Acaulospora (TRUFEM et al., 1990). Na região 
de cerrado, em culturas como algodão, arroz, beringela, milho, laranja e cana-de-açúcar, houve predomínio das espécies Gigaspora heterogama, Gigaspora pellucida e as espécies menos frequentes foram Glomus fasciculatum e Glomus gerdemannii. Na região de Cubatão/SP a ocorrência e colonização endomicorrízica foram praticamente nulas (COSTA \& BONONI, 1991).

BONONI \& TRUFEM (1983) observaram que a maior frequência de esporos de fungos foi constatada na época mais quente e úmida como ocorre com a maioria dos fungos, predominando nessa época esporos de Gigaspora calospora, $G$. heterogama, $G$. nigra e $G$. gilmorei. Na época mais fria e seca predominaram sempre em menor número esporos de diferentes espécies de Glomus, no entanto, foi evidente uma flutuação no número e tipo de esporos durane o ano. Analisou-se solo de rizosfera de culturas (arroz, cana e milho) introduzidos na mesma área de cerrado, tendo-se verificado uma certa especificidade entre os hospedeiros e os fungos endomicorrízicos. Observações semelhantes foram feitas por MOSSE \& BOWEN (1968) e LOPES \& LOMBARDI (1980), concluindo que em alguns casos, a vegetação determina a biota da rizosfera, principalmente em monoculturas.

A multiplicação de esporos de fungos MA é relacionada com o final de ciclo de vida da planta hospedeira numa tentativa de preservação da espécie (BONONI et al., 1988). No entanto, em algumas culturas estudadas, como a cevada, o número de esporos declina no final do cultivo (BLACK \& TINKER, 1979). SAITO et al. (1983) e BONONI et al. (1988); não verificaram correlação entre o número de esporos e a sua densidade; bem como entre a taxa de colonização micorrízica e o número de esporos. Nos trabalhos de MOSSE \& BOWEN 
(1968); HAYMAN et al. (1975); ABBOT \& ROBSON (1977); HAYMAN \& STOVOLD(1979); ficaram demonstrados que a população de esporos varia sazonalmante e de acordo com a cultura.

SCHENCK \& SIQUEIRA (1987) verificaram que a '-incidência de fungos $M A$ se altera quali e quantitativamente de acordo com o ecossistema, sendo influenciado por atributos do solo ( $\mathrm{pH}$, temperatura) e pela vegetação.

A colonização endomicorrízica variou desde $0 \%$ à $90 \%$ para os diferentes agro e ecossistemas - A densidade média de esporos foi de 44 e 71 esporos/50 $\mathrm{ml}$ de solo, respectivamente para ecossistemas não cultivados e agrossistemas. Verificouse que os agrossistemas são mais micotróficos, porém, mais pobres em espécies, indicando que 0 cultivo exerce modificações na comunidade de fungos micorrízicos do solo, possivelmente selecionando para a sobrevivência as espécies mais adaptadas à condição 'de elevada fertilidade do solo(SIQUEIRA et al., 1989; TRUFEM et al. 1989; COSTA \& BONONI, 1991 e CASTRO et al., 1993).

\subsection{Rizóbio}

Para a formação dos nódulos, o rizóbio, introduzido através da inoculação ou já presente no solo, precisa se multiplicar na superficie das raizes antes de penetrar. O tempo de aparecimento dos nódulos é dependente da espécie de leguminosa e estirpe de rizóbio. Geralmente nódulos são visiveis de 5 a 10 dias após o aparecimento dos mesmos. Em algumas espécies, 
como o feijoeiro, as plantas só mostram sinais evidentes de estarem sendo beneficiadas pela simbiose, 10 a 15 dias após a germinação. Em todas as leguminosas a fixação de $\mathrm{N}_{2}$ não começa até que a planta possa dispor de parte dos produtos da fotossintese para esta atividade ou até que haja um excesso de $C$ em relação ao $\mathrm{N}$ da planta (SIQUEIRA \& FRANCO, 1988 e FREIRE, 1992).

A capacidade de fixar $\circ \mathrm{N}_{2}$ atmosférico confere vantagens competitivas nos ambientes onde este elemento é limitante. Por ser o resultado de complexas reações fisiológicas e bioquímicas, muitas vezes envolvendo espécie distintas, a fixação biológica do nitrogênio (FBN) depende da expressão do potencial genético dos microrganismos diazotrófico, do hospedeiro ou de ambos, no caso de sistemas simbióticos (SIQUEIRA \& FRANCO 1988 e FREIRE, 1992).

As limitações do potencial da FBN podem ser de natureza biótica e abiótica como: estirpe de rizóbio, temperatura, umidade, $\mathrm{pH}$ do solo, concentração de nitrogênio mineral do solo, presença de $P$, presença de gases como $\mathrm{CO}_{2}$ e $\mathrm{O}_{2}$, presença de íons tóxicos de $\mathrm{Al}^{3+}$ e $\mathrm{Mn}^{2+}$, presença de Mo assimilável no solo e textura do solo (FREIRE et al. 1983; SAITO et al. 1983; VOSS e SIDIRAS 1985; VIDOR et al. 1987; SIQUEIRA \& FRANCO 1988; MOROTE et al. 1990; e CASTRO et al. 1993). De acordo com a literatura, no campo, o que tem mais limitado a FBN é a temperatura alta associada com a falta de umidade. Esse tipo de situação é frequentemente encontrada no plantio convencional, onde o solo fica descoberto e é exposto a flutuações bruscas de temperatura e umidade. No caso do plantio direto, as flutuações de temperatura são menores devido à cobertura morta no solo (BROSE \& FREIRE 1976; MUNEVAR 
\& WOLLUM 1981; MUZILLI 1983; SIDIRAS \& PAVAN, 1983 e VOSS \& SIDIRAS 1985).

A temperatura é um dos mais importantes fatores que influenciam o crescimento e a sobrevivência de Rhizobium e Bradyrhizobium no solo e suas associações simbióticas com as leguminosas. Temperaturas do solo entre 40 e $60^{\circ} \mathrm{C}$ têm sido reportadas para áreas tropicais e subtropicais, sendo em muitos casos responsáveis pela pobre nodulação das leguminosas. (MOROTE et al., 1990). A baixa umidade do solo atua sobre a nodulação e fixação de $\mathrm{N}$, além de afetar a atividade fotossintética da planta hospedeira, - que pode significar perda total ou uma redução no rendimento da cultura (SIQUEIRA \& FRANCO, 1988).

Alterações provocadas pelo sistema de plantio direto e sistema de rotação podem alterar as populações de bactérias fixadoras de $\mathrm{N}_{2}$, e também outros microrganismos do solo, dada a grande variação na incorporação dos residuos (MOROTE et al., 1990 e CASTRO et al., 1993).

VOSS \& SIDIRAS (1985) estudaram o efeito de sistemas de cultivo na nodulação da soja. Neste trabalho, os autores observaram que em solos sob plantio direto houve distribuição mais profunda de nódulos no perfil do solo, além de que, em valor absoluto, encontraram-se mais nódulos em plantio direto do que em plantio convencional, em todas as camadas analisadas. As observações feitas levam a esperar maior estabilidade na FBN em plantio direto do que em plantio convencional. CASTRO et al. (1993) também observaram que o plantio direto e o sistema de rotação causaram significativos aumentos na nodulação. 


\section{MATERIAIS E MÉTODOS}

\subsection{Caracterizaçăo edafo-climática da área}

O experimento foi instalado no Centro Experimental pertencente ao Instituto Agronômico, no munícipio de Campinas, SP, em um latossolo roxo distrófico, A moderado, textura muito argilosa, unidade Barão Geraldo (Typic Harplortox) (CASTRO, 19941). A análise granulométrica deste solo foi fornecida pela Seção de Conservação do Solo do Instituto Agronômico de Campinas/SP (Tabela 1). O clima da região de Campinas é classificado como sendo do tipo subtropical úmido com inverno seco, segundo a classificação de Koppen (CASTRO, 19941).

Os dados climáticos referentes ao período da condução do experimento foram fornecidos pela seção de Climatologia Agrícola do Instituto Agrônomico de Campinas (IAC).

1 CASTRO, O.M. (Instituto Agronômico de Campinas/SP), 1994. Comunicação Pessoal. 
Tabela 1 - Composição granulométrica do latossolo roxo distrófico muito argiloso, Unidade Barão Geraldo, na região de Campinas/SP.

\begin{tabular}{|c|c|c|c|}
\hline $\begin{array}{c}\text { PROF. } \\
\text { (om) }\end{array}$ & $\begin{array}{c}\text { AREIA } \\
(8)\end{array}$ & $\begin{array}{c}\text { SILTE } \\
(8)\end{array}$ & $\begin{array}{c}\text { ARGIIA } \\
(8)\end{array}$ \\
\hline $00-20$ & 19 & 10 & 71 \\
\hline $20-40$ & 18 & 7 & 75 \\
\hline $40-60$ & 15 & 5 & 80 \\
\hline
\end{tabular}

\subsection{Tratamentos}

Foram utilizados dois tipos de cobertura vegetal: soja (Glycine max L.) variedade IAC-16, e aveia preta (Avenna strigosa), distribuidos em dois sistemas de preparo de solo: plantio direto e plantio convencional (Tabela 2).

Tabela 2 - Sistemas de manejo de solo da área experimental, na região de Campina/SP.

PREPARO

INVERNO

VERÃO

SIGLAS

Plantio Direto

(PD) .............Aveia (AV) .... Soja Rotação com Milho (SR) .....PD SR Plantio Convencional

(PC) ............Aveia (AV)....Soja Rotação com Milho (SC) ....PC SR Plantio Direto

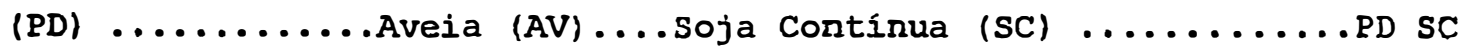
Plantio Convencional

(PC) $\ldots \ldots \ldots \ldots$. Aveia (AV) .... Soja Continua (SC) $\ldots \ldots \ldots \ldots$. PC SC 
Esse experimento de sistemas de preparo de solo foi iniciado em 1984 e conduzido pelo Instituto Agronômico de Campinas/SP (IAC), sendo, nesse período, avaliados parâmetros físicos e químicos. Os parâmetros microbiológicos não foram estudados e foram objetivo do presente trabalho.

\subsection{Delineamento experimental}

o experimento foi instalado no delineamento blocos casualizados, constando de quatro tratamentos (PDSR, PCSR, PDSC e PCSC) e duas repetições - A amostragem de solo foi realizada em 3 profundidades (0-5, 5-10, 10-20 cm), perfazendo um total de 24 amostras. Os resultados foram submetidos à análise de variância, blocos com parcelas sub-sub-divididas, e para comparação de médias foi usado o teste de Tukey ao nível de 5\% de probabilidade. Entretanto, para os parâmetros nutrientes da parte aérea, produção, nodulação utilizou-se no lugar de parcelas sub-subdivididas, blocos ao acaso.

\subsection{Instalação e condução do experimento}

- período de acompanhamento microbiológico do experimento em questão foi iniciado em 10 de julho de 1992 e se estendeu até janeiro de 1994. A semeadura de inverno foi iniciada em 11/07/92 
(aveia preta, variedade comum), no espaçamento de $15 \mathrm{~cm}$ (80-100 sementes/metro linear), sendo a adubação de 150 $\mathrm{kg} / \mathrm{ha}$ da formulação 4-20-20 (6kg/ha de $\mathrm{N}$ e $30 \mathrm{~kg} / \mathrm{ha}$ de $\mathrm{P}_{2} \mathrm{O}_{5}$ e de $\mathrm{K}_{2} \mathrm{O}$ ). Semearam-se em dois sistemas de preparos de solo: plantio direto (PD) e plantio convencional (PC), onde $O$ PC constou de uma aração mais duas gradagens. A colheita da aveia foi realizada no dia 07 de novembro de 1992.

No dia 07 de janeiro de 1993, foi feito a semeadura da cultura de verão, soja (Glycine max) variedade IAC 16, no espaçamento de 50 cm (20 plantas/metro linear), adubado com $320 \mathrm{~kg} / \mathrm{ha}$ da fórmula 0-28-15 $\left(89,6 \mathrm{~kg} / \mathrm{ha}\right.$ de $\mathrm{P}_{2} \mathrm{O}_{5}$ e 48,8 $\mathrm{kg} / \mathrm{ha}$ de $\left.\mathrm{K}_{2} \mathrm{O}\right)$, semeada em dois sistemas de preparo de solo: PD e PC. A colheita foi efetuada no dia 07 de maio de 1993.

No dia 15 de maio de 1993, foi feito a semeadura de aveia preta com espaçamento e adubação iguais ao ano anterior. A colheita foi realizada no dia 07 de outubro de 1993.

No dia 06 de janeiro de 1994, foi efetuada a semeadura da soja, com espaçamento e adubação iguais a soja do ano agrícola anterior.

\subsection{Amostragem de solo}

As amostras de solo foram retiradas nas profundidades $0-5,5-10$ e 10-20 cm, usando-se cavadeira manual. De cada parcela obteve-se uma amostra composta a partir de oito sub-amostras, envolvendo pontos obtidos na linha de plantio o mais próximo possível das plantas. Nos meses em que a cultura não se encontrava 
instalada, as amostras foram colhidas ao acaso dentro de cada parcela.

As amostragens de solo foram feitas nos dias: 10/07/1992 (inicio do experimento), 06/01/1993 (antes da semeadura da soja), 29/03/1993 (florescimento da*soja), 06/05/1993 (colheita da soja), 14/05/1993 (antes da semeadura da aveia preta), 24/07/1993 (florescimento da aveia preta), 03/10/1993 (colheita da aveia preta), 05/01/1994 (antes da semeadura da soja).

\subsection{Preparo das amostras de solo}

Para determinação da biomassa microbiana, as amostras compostas, imediatamente após a coleta, foram passadas por peneira de $2 \mathrm{~mm}$ de abertura de malha e submetidas à determinação da biomassa microbiana, segundo o método de JENKINSON \& POWLSON (1976), com pequenas modificações . Um segundo conjunto de amostras foi armazenado a $5^{\circ} \mathrm{C}$ por 28 dias e, após este período, foi submetida à determinação da biomassa. o último conjunto de amostras foi elevado à $50 \%$ da capacidade máxima de retenção de água e armazenado a $5^{\circ} \mathrm{C}$ por 15 dias, e após esse período foi submetido à determinação da biomassa microbiana, pelo mesmo método.

Após a passagem do solo por peneira de $2 \mathrm{~mm}$ de abertura, foram efetuadas as seguintes determinações: preparo do extrato para a determinação de nitrogênio do solo; para as três últimas amostragens de solo, determinou-se também a atividade da desidrogenase e fez-se a quantificação de fungos e bactérias pelo método da diluição e plaqueamento. 
Após a secagem do solo ao ar, foi feita a contagem de esporos de fungos micorrizicos arbusculares e sua posteior identificação (SCHENCK \& PËREZ, 1987).

\subsection{Análises do Solo}

\subsubsection{Umidade atual}

Foi utilizado o método gravimétrico. Aproximadamente $20 \mathrm{~g}$ de terra foram colocadas em latas de alumínio previamente taradas. Estes conjuntos, após pesagem, foram levados à estufa e mantidos a $100-110^{\circ} \mathrm{C}$ por 24 horas; depois permaneceram até atingir a temperatura ambiente em dessecador e fez-se nova pesagem.

A umidade, expressa em porcentagem na terra seca em estufa, foi calculada através da seguinte fórmula:

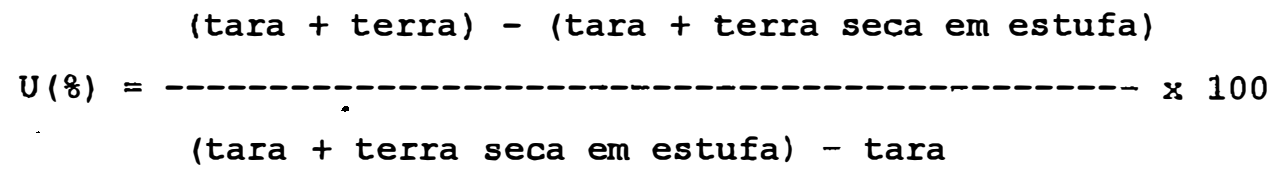




\subsection{2. $\mathbf{N}$-amoniacal e $\mathbf{N}$-(nitrato + nitrito)}

Foi utilizado o método de BREMNER (1965), - qual se baseia na extração das formas inorgânicas de $\mathbf{N}$-do solo com solução de $\mathrm{KCl} 2 \mathrm{~N}$ e determinação do $\mathrm{N}$ amoniacal no extrato filtrado, por destilação a vapor, empregando Mgo em pó para alcalinizar o meio. A amonia arrastada pelo vapor é conduzida a um condensador e recolhida junto com o destilado em uma solução de ácido bórico com indicadores, sendo em seguida titulada com $\mathrm{H}_{2} \mathrm{SO}_{4}$ padronizado.

A adição de liga de Devarda à mesma amostra promove a redução do nitrato e do nitrito à amônia, permitindo a determinação dessas formas nitricas.

\subsubsection{Determinação de $\mathrm{pH}, \mathrm{P}, \mathrm{Ca}, \mathrm{Mg}$ e $\mathrm{S}$}

As amostras de terra obtidas nas áreas experimentais antes da semeadura da aveia (10/07/1992), no plantio da soja (06/01/1993) e no semeadura da aveia (14/05/1993), após a secagem ao ar e feitas passar por peneira de $2 \mathrm{~mm}$ de abertura de malha, foram adequadamente acondicionadas e enviadas para 0 laboratório de fertilidade de solos do Departamento de Ciência do Solo da Escola Superior de Agricultura Luiz de Queiroz, Piracicaba-SP, onde foram realizadas as análises químicas.

As metodologias utilizadas na determinação do $\mathrm{pH}, \mathrm{P}, \mathrm{K}, \mathrm{Ca}$ e $\mathrm{Mg}$ encontram-se descritas em RAIJ et al. (1987). 


\subsection{Determinação de microrganismos do solo}

\subsubsection{Biomassa microbiana}

Foi utilizado 0 método de JENKINSON \&

POWLSON (1976), com pequenas modificações. Após a coleta do solo, este foi submetido imediatamente ao peneiramento, utilizando peneira com malha de $2 \mathrm{~mm}$ de abertura.

Metodologia: Duas amostras de $25 \mathrm{~g}$ foram colocadas em copos de griffin de $100 \mathrm{ml}$. A amostra a ser fumigada foi colocada em dessecador contendo um copo de griffin com clorofórmio isento de álcool. Em seguida, promoveu-se, com auxílio de bomba de vácuo, a remoção do ar contido no dessecador e a ebulição do clorofórmio durante 15 minutos. A amostra não fumigada foi colocada em dessecador e submetida ao mesmo processo descrito para a amostra fumigada, porém na ausência de clorofórmio. Os dessecadores foram revestidos com papel úmido e mantidos por 22-24 horas a $25^{\circ} \mathrm{C}$.

Passado este período, os dessecadores foram submetidos a cinco evacuações para remoção de vapores residuais de $\mathrm{CHCl}_{3}$ e de $\mathrm{CO}_{2}$ provavelmente formado.

As amostras foram colocadas em recipientes de 3,0 litros contendo um copo de griffin com 10ml de solução padronizada de $\mathrm{NaOH}$ 1N. No interior do recipiente foi colocado um copo de griffin com água destilada, de modo a evitar a perda de umidade das amostras. Fechou-se o recipiente, com auxilio de vita- 
filme e tampa, procedendo à incubação por 10 dias a $25^{\circ} \mathrm{C}$.

Terminado o período de incubação, tomouse $\circ \mathrm{NaOH}$ do frasco, acrescentando-se $2 \mathrm{ml}$ de solução de cloreto de bário saturado e duas gotas de solução alcoólica de fenolftaleina a $1 \%$ e foi efetuada a titulação com solução padronizada de $\mathrm{HCl} 0,5 \mathrm{~N}$.

A biomassa foi calculada pelo teor de C$\mathrm{CO}_{2}$ proveniente da amostra fumigada, subtraído do teor de $\mathrm{C}-\mathrm{CO}_{2}$ da amostra não fumigada, dividindo-se pelo fator $\mathrm{K}$ de conversão de $\mathrm{C}-\mathrm{CO}_{2}$ em massa microbiana $(\mathrm{K}=$ $0,45)$.

Para cada amostra de solo, em laboratório, foram feitas 3 réplicas, perfazendo um total de 72 amostras fumigadas e 72 amostras não fumigadas além de 8 brancos sem solo. A biomassa microbiana foi determinado em todas as amostras de solo nos dias: 10/07/92, 06/01/93, 29/03/93, 06/05/93, $14 / 05 / 93,24 / 07 / 93,03 / 10 / 93,05 / 01 / 94$.

\subsubsection{Atividade de desidrogenase}

Foi utilizado o método de CASIDA Jr. et al. (1964). Para cada amostra de solo utilizou-se uma aliquota de $10 \mathrm{~g}$, misturando-o com $1 \mathrm{~g}$ de $\mathrm{CaCO}_{3}$. Essa amostra foi dividida em três tubos de 16 x $150 \mathrm{~mm}$, cada um com $3 \mathrm{~g}$. Em cada tubo foi adicionado $0.5 \mathrm{ml}$ de TTC a $3 \%$ em água e $1,5 \mathrm{ml}$ de água esterilizada. Os tubos foram vedados com rolhas de borracha, para não permitir a entrada de oxigênio, incubados por 24 horas a $37^{\circ} \mathrm{C}$ no escuro. 
Passado este período o solo do tubo foi transferido para frasco de erlenmyer contendo $100 \mathrm{ml}$ de metanol e fez-se a filtração a vácuo, completando o volume a $100 \mathrm{ml}$ com metanol. A leitura foi feita em espectofotômetro, como absorbância a $480 \mathrm{~nm}$.

... A determinação da atividade de desidrogenase foi realizada nas amostragens de solo dos dias: 24/07/1993, 03/10/1993 e 05/01/1994.

Para a determinação da curva padrão utilizou-se TTC a 3\%, adicionou-se liga de Devarda para a redução do trifeniltetrazólio (TTC) a trifenilformazana (TPF) com aquecimento em banho maria. Após o pico de viragem de cor, utilizou-se $1 \mathrm{ml}$ de TPF, completando $\circ$ volume à $100 \mathrm{ml}$ de metanol. Em dez tubos de ensaio adicionaram-se em triplicata $0.1 ; 0.5 ; 1.0$; $1.5 ; 2.0 ; 2.5 ; 3.0 ; 4.0$ e $5 \mathrm{ml}$ de TPF. A leitura foi realizada em espectrofotômetro, como absorbância a 480 nm.

\subsubsection{Bactérias e fungos}

A quantificação de bactérias e fungos foi realizada pela técnica do NMP (número mais provável), em tubo de cultura com cinco réplicas, fazendo-se diluição à extinção e utilizando os meios de Martin para fungos e meio de nutriente ágar para bactérias.

A quantificacão de fungos e bactérias foi realizada nas amostras de um dos blocos com os quatro tratamentos, à profundidade de $0-5 \mathrm{~cm}$, nas amostragens de solo dos dias: 24/07/1993, 03/10/1993 e 05/01/1994. Devido ao fato de não terem sido feitas repetições de campo, não foi realizada análise estatistica. 


\title{
3.8.4. Contagem e identificaçảo de esporos
}

\begin{abstract}
Em todas as amostras de solo, após a secagem ao ar, foi efetuada a contagem de esporos de fungos $\mathrm{MA}$ em $50 \mathrm{ml}$ de solo, utilizando-se o método de peneiramento úmido de GERDEMANN \& NICOLSON (1963) e a técnica de centrifugação de frações de peneiramento do solo (LOPES et al., 1983). Quando possível fez-se a identificação dos esporos (SCHENCK \& PÉREZ, 1987).
\end{abstract}

\subsection{Análises de plantas}

\subsubsection{Amostragens}

\begin{abstract}
As amostragens de parte aérea e raiz foram realizadas no início do florescimento, correspondendo aos dias: 25/10/1992 (aveia); 25/03/1993 (soja); 20/07/1993 (aveia).
\end{abstract}

\subsubsection{Análise química da parte áerea}

A parte aérea foi seca em estufa a $65^{\circ} \mathrm{C}$, finamente moida para determinação de nitrogênio pelo método de KJELDAHL, com digestão em ácido sulfúrico (MALAVOLTA et al., 1989) e para determinação de $\mathrm{P}, \mathrm{K}$, $\mathrm{Ca}, \mathrm{Mg}, \mathrm{S}, \mathrm{Cu}, \mathrm{Fe}, \mathrm{Mn}, \mathrm{e} \mathrm{Zn}$ pelo método da digestão nitro-perclórica (MALAVOLTA et al., 1989). Para cada parcela, foram coletados 10 plantas. 


\subsubsection{Amostragens de raizes}

A porcentagem de colonização micorrízica foi determinada pelo método de coloração de raizes (PHILLIPS \& HAYMANN, 1970) e avaliação em placa quadriculada (GIOVANETTI \& MOSSE, 1980). A porcentagem de colonizacão micorrízica foi realizada nas três amostragens de raiz (25/10/92 (aveia); 25/03/93 (soja) e 20/07/93 (aveia)) e, para cada parcela, foram coletado seis sistemas radiculares de plantas.

\subsubsection{Nodulação}

No início do florescimento da soja (25/03/1992), foi efetuada a coleta e contagem de nódulos, que posteriormente foram secos a $65^{\circ} \mathrm{C}$ e pesados. Foi feita a pesagem do sistema radicular, após secagem em estufa. Para cada parcela foram coletados oito sistemas radiculares de plantas de soja.

\subsubsection{Avaliação da produção}

A avaliação da produção da soja e aveia preta foi realizada pelo Instituto Agronômico de Campinas (IAC), com a colheita manual em parcelas de $2.5 \times 2.0 \mathrm{~m}\left(5 \mathrm{~m}^{2}\right)$. Pesou-se todo material, tirou-se uma amostra de cada parcela, pesou-se, secou-se a $65^{\circ} \mathrm{C}$ por 48 horas, pesando-as novamente para o cálculo da 
umidade da massa e correção para massa seca. Os pesos de grãos de soja foram corrigidos para 13\% de umidade. 


\section{RESULTADOS E DISCUSSÃo}

\subsection{Dados climáticos}

Os dados climáticos foram fornecidos pela Seção de Climatologia do Instituto Agronômico de Campinas/SP (IAC) localizado à latitude: 22G54'S; longitude: 47G05'W e altitude: $674 \mathrm{~m}$, para a região de Campinas/SP, apresentados na Tabela 3.

\subsection{Umidade do solo}

Os diferentes sistemas de manejo do solo (Tabela 4) não influenciaram o teor de umidade do solo, mas o teor de umidade do solo foi maior para a profundidade 20-30 cm, resultado esperado, uma vez que a evapotranspiração atua mais pronunciadamente sobre as camadas superficiais, permanecendo um teor maior nas camadas mais profundas. O fator época de amostragem influenciou a umidade do solo, obtendo maiores teores de umidade nas épocas mais pluviosas, visto que os meses de janeiro, março, outubro foram os de maior pluviosidade (Tabela 3). 
Tabela 3 - Dados Climáticos referentes aos meses de julho/92 a janeiro/94, para a região de Campinas/sP.

\begin{tabular}{|l|l|l|l|l||}
\hline MESES & $\begin{array}{c}\text { TEMPERATURA } \\
\text { MÉDIA }\end{array}$ & $\begin{array}{c}\text { TEMPERATURA } \\
\text { MÍNIMA }\end{array}$ & $\begin{array}{c}\text { TEMPARATURA } \\
\text { MÁXIMA }\end{array}$ & $\begin{array}{c}\text { PRECIPITAÇÃO } \\
\text { (mm) }\end{array}$ \\
\hline JULHO/92 & 19,3 & 12,9 & 30,8 & 12,8 \\
\hline SETEMBRO/92 & 20,1 & 15,5 & 30,4 & 94,2 \\
\hline OUTUBRO/92 & 22,4 & 17,1 & 32,2 & 249,6 \\
\hline NOVEMBRO/92 & 22,8 & 17,4 & 32,4 & 222,1 \\
\hline DEZEMBRO/92 & 23,4 & 17,6 & 33,2 & 147,5 \\
\hline JANEIRO/93 & 24,6 & 19,6 & 34,6 & 238,4 \\
\hline FEVEREIRO/93 & 23,1 & 18,7 & 31,6 & 310,7 \\
\hline MARÇO/93 & 24,1 & 18,8 & 32,6 & 132,7 \\
\hline ABRIL/93 & 22,9 & 17,5 & 31,0 & 87,8 \\
\hline MAIO/93 & 20,0 & 14,6 & 28,8 & 108,0 \\
\hline JUNHO/93 & 18,1 & 12,5 & 27,0 & 47,5 \\
\hline JULHO/93 & 19,4 & 13,0 & 30,6 & 12,0 \\
\hline AGOSTO/93 & 18,4 & 11,4 & 33,4 & 41,2 \\
\hline SETEMBRO/93 & 20,9 & 15,3 & 33,2 & 143,9 \\
\hline OUTUBRO/93 & 23,2 & 17,3 & 33,6 & 80,5 \\
\hline NOVEMBRO/93 & 25,1 & 19,2 & 31,1 & 106,4 \\
\hline DEZEMBRO/93 & 24,2 & 19,3 & 29,1 & 200,6 \\
\hline JANEIRO/94 & 24,1 & 19,1 & 29,1 & 213,0 \\
\hline
\end{tabular}


Tabela 4 - Umidade do solo (\%) para diferentes sistemas de manejo do solo, a diferentes profundidades e épocas de amostragem de solo, na região de Campinas/SP.

\begin{tabular}{|l|c|}
\hline \multicolumn{1}{|c|}{ TRATAMENTO } & UMIDADE DO SOLO \\
\hline MANEJO DO SOLO & $15,07 \mathrm{a}$ \\
SCPD & $14,63 \mathrm{a}$ \\
SCPC & $15,16 \mathrm{a}$ \\
SRPD & $14,91 \mathrm{a}$ \\
SRPC & \\
\hline PROFUNDIDADE (cm) & $14,90 \mathrm{~b}$ \\
O-5 & $14,93 \mathrm{~b}$ \\
I0-20 & $14,99 \mathrm{a}$ \\
20-30 & \\
\hline EPOCAS & $12,62 \mathrm{~g}$ \\
JUL/92 & $17,53 \mathrm{~b}$ \\
JAN/93 & $15,66 \mathrm{c}$ \\
MAR/93 & $12,83 \mathrm{f}$ \\
MAI/93 & $15,32 \mathrm{~d}$ \\
MAI/93 & $12,82 \mathrm{f}$ \\
JUL/93 & $15,08 \mathrm{e}$ \\
OUT/93 & $17,68 \mathrm{a}$ \\
\hline JAN/94 & 8,63 \\
\hline CV (\%) & \\
\hline
\end{tabular}

* médias seguidas da mesma letra não diferem significativamente entre si. 


\subsection{Fertilidade do solo}

Os resultados da análise de fertilidade do solo antes da instalação do experimento e plantio da aveia preta, (10/07/92), antes do plantio da soja (06/01/93) e antes do plantio da aveia preta (14/05/93), não tiveram diferenças significativas entre si ao nível de 5\% de probabilidade, permanecendo constantes os teores dos nutrientes durante a condução do experimento.

Observa-se que os solos sob plantio direto apresentaram os maiores teores de matéria orgânica e que este teor diminuiu com 0 aumento da profundidade de amostragem de solo, sendo que a profundidade 0-5 cm diferiu significativamente das demais (Tabelas 5 e 6 ). Como no plantio direto não ocorre a incorporação dos resíduos vegetais, ficando esses à superfície do solo, favorece-se um maior teor de matéria orgânica no plantio direto na superfície, resultados estes que confirmam observações anteriores de CASTRO et al., (1987); CASTRO, (1986ab); SILVA \& VIDOR, (1984); BLEVINS et al., (1983); MUZILLI, (1983); CANNEL \& FINNEY, (1979) e DE MARIA \& CASTRO, (1993). 
Tabela 5 - Características químicas do solo da área experimental na região de Campinas/SP 1 .

\begin{tabular}{|c|c|c|c|c|c|c|c|c|c|c|}
\hline & $\mathrm{pH}$ & $\begin{array}{l}\text { M.O. } \\
\left(\frac{0}{0}\right)\end{array}$ & $\begin{array}{c}P \\
\mathrm{ug} / \mathrm{cm}^{3}\end{array}$ & $\mathrm{~K}$ & $\begin{array}{l}\mathrm{Ca} \\
\mathrm{me}\end{array}$ & $\mathrm{Mg}$ & $\mathrm{H}+\mathrm{Al}$ & $\mathrm{SB}$ & $\mathrm{T}$ & $\begin{array}{l}\mathrm{V} \\
\left(\frac{\circ}{0}\right)\end{array}$ \\
\hline \multicolumn{11}{|l|}{ manejo } \\
\hline SCPD & $5,5 \mathrm{a}$ & $3,6 \mathrm{a}$ & $83 a$ & $0,51 a$ & $5,92 a$ & $1,78 a$ & $2,75 b$ & $8,22 a$ & $11,0 a$ & $75,5 a$ \\
\hline SCPC & $5,0 \mathrm{~b}$ & $3,0 \mathrm{~b}$ & $50 \quad \mathrm{~b}$ & $0,51 a$ & $3,05 c$ & $0,95 c$ & $3,67 a$ & $4,53 c$ & $8,20 \mathrm{c}$ & $55,0 \mathrm{~b}$ \\
\hline SRPD & $5,1 \mathrm{~b}$ & $3,6 \mathrm{a}$ & $74 \quad \mathrm{a}$ & $0,28 a$ & $4,40 \mathrm{~b}$ & $1,38 \mathrm{~b}$ & $3,63 a$ & $6,07 \mathrm{~b}$ & $9,7 \mathrm{ba}$ & $62,3 b$ \\
\hline SRPC & $4,9 \mathrm{~b}$ & $3,1 \mathrm{~b}$ & $39 \quad \mathrm{~b}$ & $0,44 a$ & $3,47 \mathrm{~b}$ & $1,1 \mathrm{cb}$ & $3,93 a$ & $5,00 \mathrm{~b}$ & $9,0 \mathrm{bc}$ & $55,3 b$ \\
\hline \multicolumn{11}{|l|}{$\begin{array}{l}\text { PROF. } \\
(\mathrm{cm})\end{array}$} \\
\hline $0-5$ & $5.2 \mathrm{~A}$ & $3,9 \mathrm{~A}$ & $81 \mathrm{~A}$ & $0,59 \mathrm{~A}$ & $4,34 \mathrm{~A}$ & $1,46 \mathrm{~A}$ & $3,35 \mathrm{~A}$ & $6,16 \mathrm{~A}$ & $9,75 \mathrm{~A}$ & $64,1 \mathrm{~A}$ \\
\hline $5-10$ & $5,1 \mathrm{~A}$ & $3,2 \mathrm{~B}$ & $63 \quad \mathrm{~B}$ & $0,40 \mathrm{~A}$ & $4,19 \mathrm{~A}$ & $1,26 \mathrm{~A}$ & $3,61 \mathrm{~A}$ & $5,86 \mathrm{~A}$ & $9,47 \mathrm{~A}$ & $60,9 \mathrm{~A}$ \\
\hline $10-20$ & $5,1 \mathrm{~A}$ & $2,7 \mathrm{~B}$ & $41 \quad$ B & $0,32 \mathrm{~A}$ & $4,10 \mathrm{~A}$ & $1,20 \mathrm{~A}$ & $3,52 \mathrm{~A}$ & $5,64 \mathrm{~A}$ & $9,16 \mathrm{~A}$ & $60,8 \mathrm{~A}$ \\
\hline CV 8 & 6,15 & 6,86 & 26,71 & 27,12 & 21,12 & 21,49 & 17,89 & 20,38 & 9,68 & 13,15 \\
\hline
\end{tabular}

* médias seguidas por letras minúsculas iguais, na vertical, não diferem significativamente entre si.

** médias seguidas por letras maiúsculas iguais, na vertical, não diferem significativamente entre si. 1 valores médios obtidos para as três épocas de amostragem de solo (início do experimento,
semeaduras da aveia e soja). 
Tabela 6 - Desdobramento pelo teste de Tukey de manejo do solo x profundidade de amostragem para os parâmentros M.O., $\mathrm{P}, \mathrm{Ca}, \mathrm{Mg}$ e $\mathrm{pH}$.

\begin{tabular}{|c|c|c|c|c|}
\hline \multirow{2}{*}{$\begin{array}{l}\text { PROFUNDIDADE } \\
\text { (cm) }\end{array}$} & \multicolumn{4}{|c|}{ MANEJO DO SOLO } \\
\hline & SCPD & SCPC & SRPD & SRPC \\
\hline M.O. (응) & & & & \\
\hline $0-5$ & 4,5 aA & $3,5 \mathrm{bB}$ & 4,4 aA & $3,4 \mathrm{bA}$ \\
\hline $5-10$ & 3,3 aB & $3,2 \mathrm{aB}$ & $3,6 \mathrm{aB}$ & $3,2 \mathrm{aB}$ \\
\hline $10-20$ & $2,8 \mathrm{aC}$ & $3,2 \mathrm{aB}$ & $2,9 \mathrm{aC}$ & $3,0 \mathrm{aB}$ \\
\hline CV & $6,56 \div$ & & & \\
\hline$P\left(\mathrm{ug} / \mathrm{cm}^{3}\right)$ & & & & \\
\hline $0-5$ & $120 \mathrm{aA}$ & $47 \mathrm{bA}$ & 80 aA & $40 \mathrm{bA}$ \\
\hline $5-10$ & $78 \mathrm{aB}$ & $50 \mathrm{abA}$ & 84 aA & $40 \mathrm{bA}$ \\
\hline $10-20$ & $53 \mathrm{aB}$ & $43 \mathrm{aA}$ & $50 \mathrm{aB}$ & $52 \mathrm{aA}$ \\
\hline $\mathrm{CV}$ & $15,11 \%$ & & & \\
\hline $\mathrm{Ca} \quad\left(\mathrm{meq} / 100 \mathrm{~cm}^{3}\right)$ & & & & \\
\hline $0-5$ & 6,3 aA & $3,2 \mathrm{bA}$ & 4,7 aA & $3,4 \mathrm{bA}$ \\
\hline $5-10$ & 6,0 aA & $2,9 \mathrm{CA}$ & $4,6 \mathrm{abA}$ & $3,5 \mathrm{bA}$ \\
\hline $10-20$ & 5,7 aA & $3,1 \mathrm{bA}$ & $4,4 \mathrm{abA}$ & $3,8 \mathrm{bA}$ \\
\hline CV & $12,53 \%$ & & & \\
\hline $\operatorname{Mg}\left(\mathrm{meq} / 100 \mathrm{~cm}^{3}\right)$ & & & & \\
\hline $0-5$ & 2,1 aA & $1,1 \mathrm{bA}$ & 1,6 aA & $1,2 \mathrm{bA}$ \\
\hline $5-10$ & $1,8 \mathrm{aA}$ & $0,9 \mathrm{bA}$ & $1,4 \mathrm{abA}$ & $1,1 \mathrm{bA}$ \\
\hline $10-20$ & 1,7 aA & $0,9 \mathrm{bA}$ & $1,3 \mathrm{abA}$ & $1,2 \mathrm{abA}$ \\
\hline $\mathrm{CV}$ & $12,7 \%$ & & & \\
\hline $\mathrm{pH}$ & & & & \\
\hline $0-5$ & $5,5 \mathrm{aA}$ & $5,0 \mathrm{bA}$ & $5,2 a b A$ & $5,0 \mathrm{bA}$ \\
\hline $5-10$ & $5,5 \mathrm{aA}$ & $5,1 \mathrm{bA}$ & $5,1 \mathrm{bA}$ & $4,9 \mathrm{bA}$ \\
\hline $10-20$ & 5,4 aA & $5,0 \mathrm{bA}$ & $5,0 \mathrm{bA}$ & $4,9 \mathrm{bA}$ \\
\hline
\end{tabular}

* médias seguidas por letras minúsculas iguais, na horizontal, nåo diferem significtivamente entre si .

** médias seguidas por letras maiúsculas iguais, na vertical, nåo diferem significativamente entre si. 
Também foi encontrado que solos sob plantio direto apresentaram os maiores teores de fósforo (P) (Tabelas 5 e 6). Deve-se salientar que 0 tratamento com soja contínua recebeu maior adubação de $P$ no decorrer dos anos do que o tratamento com soja rotação, pois a cultura da soja é mais exigente em $\mathrm{P}$ que 0 milho, $O$ que se reflete numa concentração máxima de $\mathrm{P}$ no solo deste tratamento. $\mathrm{O} P$ possui uma baixa mobilidade e solubilidade, sobretudo em solos contendo altos teores de argila (Tabela 2) e sesquióxidos de ferro, podendo nestas circunstâncias, ocorrer 0 fenômeno da fixação do $P$ pelas argilas do solo. Verificou-se que $O$ teor de $P$ foi diminuindo com $O$ aumento da profundidade de amostragem de solo; em todas as amostragens $O$ teor de $P$ na superfície diferiu significativamente da profundidade $10-20 \mathrm{~cm} ;$ com exceção para o PC. Houve, portanto, um acúmulo deste nutriente nos primeiros $10 \mathrm{~cm}$ do solo para $O$ PD. Resultados semelhantes foram obtidos por MUZILLI, (1983); CASTRO et al. (1992) e DE MARIA \& CASTRO, (1993) .

Os teores de $\mathrm{P}$ encontrados no solo variaram de 40 a $120 \mathrm{ug} / \mathrm{cm}^{3}$ (Tabelas 6) apresentando-se na maioria dos casos teores altos de $\mathrm{P}$ no solo segundo RAIJ et al., (1992).

Observa-se que, no caso do potássio (K) (Tabelas 5), não houve diferença significativa entre os sistemas de manejo de solo nem entre as três profundidades amostradas, 0 que concorda com os resultados de THOMAS (1980); MUZILLI (1983) e ELTZ et al. (1989), pois o $\mathrm{K}$ aplicado na superfície do solo em sistema de plantio direto tem sido encontrado distribuido no perfil do solo da mesma maneira que o $\mathrm{K}$ incorporado em sistema de preparo convencional. 
Entretanto, o acúmulo ou não de $K$ no solo vai depender do tipo de solo (textura, mineral de argila), do regime de drenagem e da quantidade adicionada na adubação.

O teor de $K$ encontrado no solo variou num intervalo de 0,28 a $0,51 \mathrm{meq} / 100 \mathrm{~cm}^{3}$ (Tabelas 5), representando teores médios a altos (RAIJ et al., 1992).

Na Tabela 6, observa-se que os teores de cálcio (Ca) e magnésio ( $\mathrm{Mg}$ ) foram influenciados pelos diferentes sistemas de manejo de solo e não foram influenciados pelo fator profundidade de amostragem; os tratamentos sob plantio direto tiveram teores maiores de $\mathrm{Ca}$ e $\mathrm{Mg}$ do que o PC, e dentro do PD, o sistema de soja rotação obteve menores teores de $\mathrm{Ca}$ e $\mathrm{Mg}$, com reflexos nos valores de $\mathrm{pH}$ do solo. Esses resultados não corroboram os de CASTRO et al. (1987), que não verificaram diferenças nos diferentes sistemas de preparo de solo nesta mesma área experimental. Segundo RAIJ et al., (1992) esse solo possui teor alto de Mg e Ca.

No plantio direto, a calagem foi feita sem incorporação do corretivo e no plantio convencional foi feita sua incorporação, provável causa das diferenças encontradas, afetando, ainda, $\mathrm{O}$ pH, CTC e V\%. Para o fator profundidade, não houve diferença significativa para o $\mathrm{Ca}$ e Mg (Tabelas 6), indicando que, em solos com boa drenagem, é possível corrigir camadas mais profundas sem a necessidade de incorporar - corretivo com aração, conforme também foi observado por MUZILLI (1981) em latossolo roxo e CENTURION \& DEMATTÊ (1985) para latossolo vermelho-escuro argiloso. Teores de N-amoniacal e N-(nitrato + nitrito) do solo durante o período de condução do 
experimento não foram influenciados pelos fatores manejo do solo e profundidade amostrada; a época de amostragem afetou o seu teor. Observa-se que os maiores valores de $\mathrm{N}$ foram obtidos em julho/93 e outubro correspondendo às épocas de florescimento e colheita da aveia e a períodos de relativamente baixa pluviosidade, principalmente para o mês de julho (Tabela 7). Os meses mais pluviosos apresentaram os menores teores de $\mathrm{N}$, o que pode estar relacionado com a lixiviação de nitratos. THOMAS (1980) verificou lixiviação de nitratos em diferentes sistemas de preparo do solo e menor taxa de mineralização de $\mathrm{N}$ em $\mathrm{PD}$, resultados também verificados por MUZILLI (1983). Os teores encontrados no presente estudo correspondem a um teor médio de $\mathrm{N}$, segundo KIEHL (1995) ${ }^{1}$.

É possivel que essas diferenças encontradas na concentração de nutrientes entre PD e PC mencionadas acima, também possam estar relacionadas ao processo de erosão que, sendo maior no PC, este apresentou teores menores de nutrientes, pois, no PD a erosão é muito menor; principalmente no caso do $P$.

'KIEHL, J.C. (Escola Superior de Agricultura "Luiz de Queiroz" USP, Piracicaba, SP). Comunicação Pessoal, 1995. 
Tabela 7 - N-amoniacal e N-(nitrato + nitrito) do solo em diferentes manejo do solo, profundidade e época amostrada.

\begin{tabular}{|l|c|}
\hline \multicolumn{1}{|c|}{ TRATAMENTO } & N-amoniacal e N-(nitrato + nitrito) \\
\hline MANEJO DO SOLO & $94,09 \mathrm{a}$ \\
SCPD & $89,04 \mathrm{a}$ \\
SCPC & $88,88 \mathrm{a}$ \\
SRPD & $92,99 \mathrm{a}$ \\
SRPC & 20,5 \\
CV (\%) & \\
\hline PROFUNDIDADE (Cm) & $92,91 \mathrm{a}$ \\
0-5 & $90,34 \mathrm{a}$ \\
10-20 & $90,50 \mathrm{a}$ \\
20-30 & 14,62 \\
CV (o) & \\
\hline ÉPOCAS & $81,37 \mathrm{c}$ \\
JUL/92 (semeadura da aveia) & $59,15 \mathrm{~d}$ \\
JAN/93 (semeadura de soja) & $79,70 \mathrm{c}$ \\
MAR/93 (florescimento soja) & $62,41 \mathrm{~d}$ \\
MAI/93 (colheita da soja) & $73,96 \mathrm{c}$ \\
MAI/93 (semeadura da aveia) & $134,92 \mathrm{a}$ \\
JUL/93 (florescimento aveia) & $106,61 \mathrm{~b}$ \\
OUT/93 (colheita da aveia) & $74,20 \mathrm{c}$ \\
JAN/94 (semeadura da soja) & 18,33 \\
\hline CV (o) & \\
\hline
\end{tabular}

* teste de Tukey foi feito separado para manejo de solo, profundidade e época.

** médias seguidas da mesma letra não diferem significativamente entre si. 


\subsection{Quantificação de fungos e bactérias}

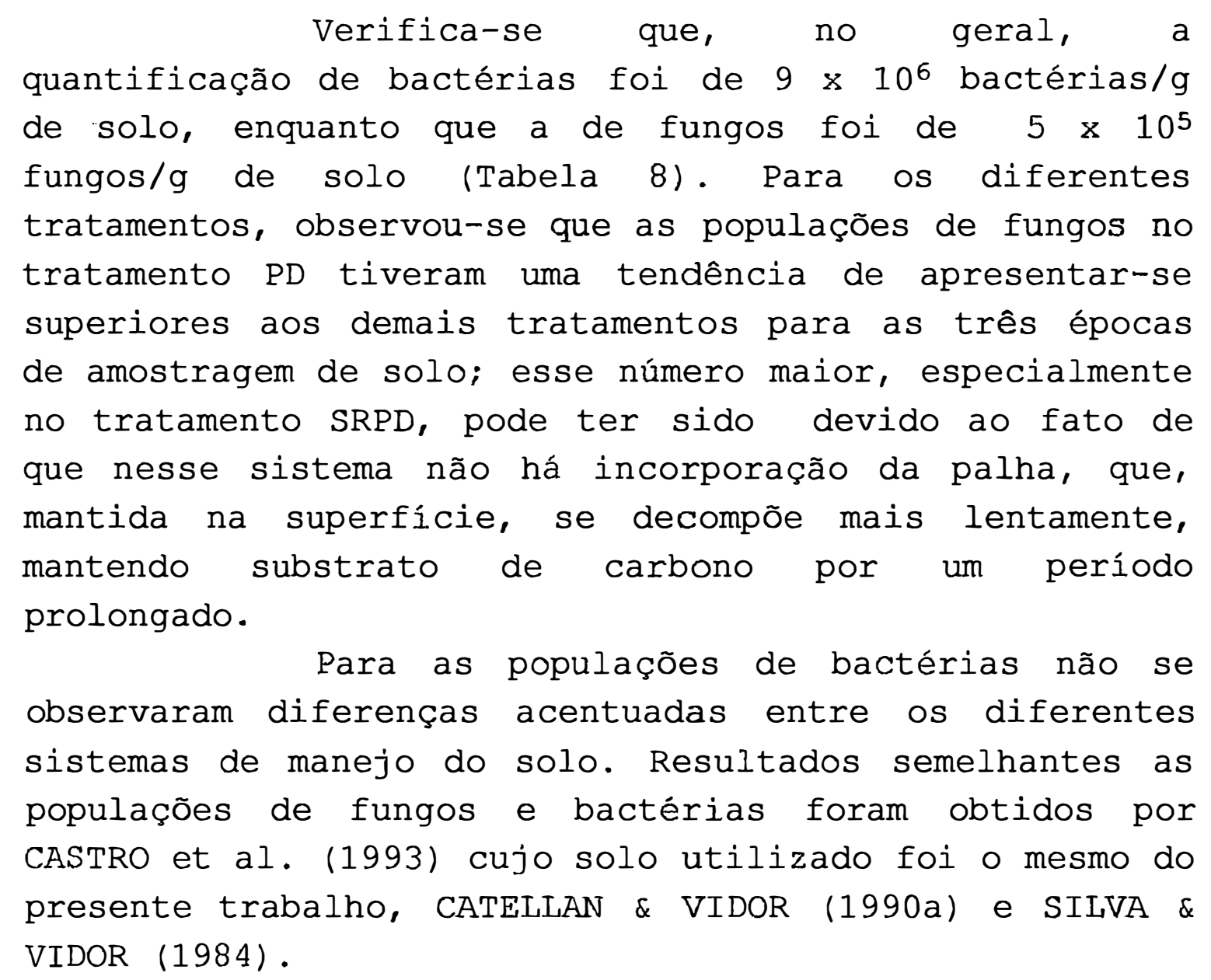


Tabela 8 - Quantifição de fungos e bactérias sob diferentes sistemas de manejo em latossolo roxo distrófico na região de Campinas/SP.

\begin{tabular}{|c|c|c|c|c|}
\hline \multicolumn{2}{|c|}{ TRATAMENTOS } & $\begin{array}{c}\text { AVEIA } \\
(24 / 07 / 93)\end{array}$ & $\begin{array}{c}\text { AVEIA } \\
(03 / 10 / 93)\end{array}$ & $\begin{array}{c}\text { SOJA } \\
(05 / 01 / 94)\end{array}$ \\
\hline \multirow[t]{2}{*}{$\mathrm{SCPD}$} & FUNGOS & $8 \times 10^{5}$ & $11 \times 10^{4}$ & $4,5 \times 10^{5}$ \\
\hline & BACTÉRIAS & $8 \times 10^{6}$ & $3,5 \times 10^{6}$ & $17 \times 10^{6}$ \\
\hline \multirow[t]{2}{*}{ SCPC } & FUNGOS & $3,5 \times 10^{5}$ & $13 \times 10^{4}$ & $8 \times 10^{5}$ \\
\hline & BACTÉRIAS & $3,5 \times 10^{6}$ & $8 \times 10^{5}$ & $5 \times 10^{6}$ \\
\hline \multirow[t]{2}{*}{ SRPD } & FUNGOS & $2,5 \times 10^{6}$ & $5 \times 10^{5}$ & $3,5 \times 10^{6}$ \\
\hline & BACTÉRIAS & $8 \times 10^{6}$ & $3,5 \times 10^{6}$ & $25 \times 10^{6}$ \\
\hline \multirow[t]{2}{*}{ SRPC } & FUNGOS & $4 \times 10^{5}$ & $3,5 \times 10^{4}$ & $3,5 \times 10^{5}$ \\
\hline & BACTÉRIA & $5 \times 10^{6}$ & $2,5 \times 10^{6}$ & $25 \times 10^{6}$ \\
\hline
\end{tabular}

* número de bactérias/g de solo; número de fungos/g de solo.

\subsection{Biomassa microbiana do solo}

Observou-se que o valor da biomassa microbiana foi sempre maior em solos sob plantio direto (PD) do que sob preparo convencional (PC). Foi observado também que a biomassa microbiana decresceu com o aumento da profundidade do solo (Tabela 9). Vários autores encontraram resultados que corroboram o presente estudo ( CAMPBELL \& BIEDERBERCK, 1976; DORAN, 1980; CAMPBELL, 1982; GRISI \& GRAY, 1986; VANCE \& JENKINSON, 1987; GRISI, 1984; FIALHO et al., 1991; PAVAN, 1991; CATTELAN \& BORKET, 1994 e CATTELAN \& TORRES, 1994). Essa variação é provavelmente ao efeito 
da cobertura vegetal bem como do manejo do solo, pois o aporte de material orgânico na superfície do solo irá fornecer o carbono necessário para o desenvolvimento dos microrganismos do solo. De fato, foi observado que - conteúdo de matéria orgânica na superfície do solo foi maior do que em profundidade e a matéria orgânica foi superior no plantio direto (Tabela 6), bem como os teores de $\mathrm{P}, \mathrm{Ca}$ e $\mathrm{Mg}$ do solo também foram superiores para o plantio direto (Tabela 6). Estes resultados influenciaram a superioridade da biomassa microbiana em solo sob plantio direto na superfície.

Verificou-se que, dentro de um mesmo sistema de preparo de solo, houve tendência do SR apresentar-se superior ao SC (Tabela 9). Isto pode estar relacionado com o fato de que a cultura de milho, possuindo em sua composição maiores teores de celulose e lignina, ser um material mais difícil de se decompor, quando comparado com a soja. Assim, na SR, O Corgânico fica por mais tempo disponível no solo do que na SC, na qual o matérial orgânico se decopõe mais rapidamente. Portanto, verifica-se que a biomassa microbiana foi influenciada pelo preparo do solo bem como pelo sistema de rotação de culturas. Embora SILVA \& VIDOR (1984) não tenham observado influência da cobertura vegetal sobre a biomassa microbiana, a grande maioria dos autores verificou que havia influencia da cobertura vegetal (DORAN, 1980; CAMPBELL, 1982; NUERNBERG et al., 1984; CARTER, 1986; PAVAN, 1991; ; CARTER \& RENNIE, 1992 e PFENNING et al., 1992 ). 
Tabela 9 - Desdobramento, pelo teste de Tukey, da interação manejo do solo x profundidade de amostragem para biomassa microbiana do solo.

\begin{tabular}{|c|c|c|c|c|}
\hline $\begin{array}{l}\text { PROFUNDIDADE } \\
(\mathrm{cm})\end{array}$ & \multicolumn{4}{|c|}{$\begin{array}{lcc}\text { BIOMASSA } & \text { MICROBIANA DO SOLO } \\
---(\mu \mathrm{g} & \left.\mathrm{C}-\mathrm{CO}_{2} / \mathrm{g} \text { solO }\right) & ------- \\
\text { SCPC } & \text { SRPD } & \text { SRPC }\end{array}$} \\
\hline $\begin{array}{l}1 \text { MÉTODO } \\
0-5 \\
5-10 \\
10-20\end{array}$ & $\begin{array}{rl}174,5 & \mathrm{bA} \\
97,9 & \mathrm{bB} \\
73,8 & \mathrm{bC}\end{array}$ & $\begin{array}{ll}96,5 & \mathrm{CA} \\
65,2 & \mathrm{CB} \\
44,6 & \mathrm{CC}\end{array}$ & $\begin{array}{r}264,1 \text { aA } \\
148,5 \text { aB } \\
94,7 \text { aC }\end{array}$ & $\begin{array}{rl}112,7 & \mathrm{CA} \\
73,1 & \mathrm{CB} \\
44,7 & \mathrm{CC}\end{array}$ \\
\hline $\begin{array}{l}2 \text { MÉTODO } \\
0-5 \\
5-10 \\
10-20 \\
\end{array}$ & $\begin{array}{rl}163,6 & \mathrm{bA} \\
89,7 & \mathrm{bB} \\
68,4 & \mathrm{aC} \\
\end{array}$ & $\begin{array}{l}91,9 \mathrm{dA} \\
61,9 \mathrm{cB} \\
45,6 \mathrm{bC}\end{array}$ & $\begin{array}{r}251,9 \text { aA } \\
102,7 \text { aB } \\
69,8 \text { aC } \\
\end{array}$ & $\begin{array}{r}109,0 \mathrm{cA} \\
65,3 \mathrm{cB} \\
47,8 \mathrm{bC} \\
\end{array}$ \\
\hline $\begin{array}{l}3 \text { MÉTODO } \\
0-5 \\
5-10 \\
10-20\end{array}$ & $\begin{array}{rl}226,3 & \mathrm{bA} \\
104,4 & \mathrm{aB} \\
74,7 & \mathrm{aC}\end{array}$ & $\begin{array}{rl}102,7 & \mathrm{CA} \\
67,7 & \mathrm{bB} \\
47,1 & \mathrm{bC}\end{array}$ & $\begin{array}{r}301,6 \text { aA } \\
112,3 \text { aB } \\
80,2 \text { aC }\end{array}$ & $\begin{array}{rl}118,2 & \mathrm{CA} \\
78,1 & \mathrm{bB} \\
51,5 & \mathrm{bC}\end{array}$ \\
\hline médias seg & de mesma & tra maiúsc & a, na verti & $\begin{array}{l}\text { l, não difer } \\
\text { l, não difer }\end{array}$ \\
\hline
\end{tabular}

O preparo do solo provavelmente influiu nas taxas de aeração do solo (conforme já é conhecido por dados de literatura) e na disponibilidade de nutrientes (Tabelas 5 e 6) pois, a incorporação dos residuos orgânicos favorece a aeração 0 que, concomitantemente com a introdução dos resíduos vegetais, acelera a atividade microbiana e consequentemente, a sua rápida decomposição. Portanto 
em espaços de tempo bem mais reduzidos a matéria energética já deve ter sido esgotada nestes tratamentos, o que teria como consequência uma redução de biomassa microbiana, o que confirma observações de NUERBERGER et al. (1984); CARTER (1986); CATTELAN \& VIDOR (1990ab); CARTER \& RENNIE (1992) e GERALDES (1993) .

A biomassa microbiana do solo foi influenciada pelo fator época de amostragem (Tabela 10), verificando-se que os maiores valores de biomassa ocorreram nos meses mais quentes e mais pluvioso da região de Campinas/SP (Tabela 3); os menores valores de biomassa foram observados nos meses mais frios e menos pluvioso (Tabela 3), com exceção para o método 3, no qual a umidade do solo foi elevada a 50\% da c.c.. Havendo em todas as diferentes épocas uma superioridade do solo sob PD em relação ao PC. Inúmeros trabalhos verificaram a influência das condições climáticas, principalmente temperatura e umidade, sobre a biomassa, corroborando o presente estudo (CATTELAN \& VIDOR, 1990ab; PAVAN, 1991; PFENNING et al., 1992; CATTELAN \& GAUDÊNCIO, 1994; CATTELAN \& TORRES, 1994 e CATTELAN \& BORKET, 1994). 
Tabela 10 - Desdobramento, pelo teste de Tukey, da interação manejo de solo x época de amostragem para os diferentes métodos de biomassa microbiana do solo.

\begin{tabular}{|c|c|c|c|c|}
\hline ÉPOCAS & $\begin{array}{l}\mathrm{BI} \\
\mathrm{SCPD}\end{array}$ & $\begin{array}{l}\text { MASSA MICRO } \\
\left(\mu \mathrm{g} \mathrm{C}-\mathrm{CO}_{2} / \mathrm{g}\right. \\
\mathrm{SCPC}\end{array}$ & $\begin{array}{l}\text { IANA DO SOI } \\
\text { de solo) } \\
\text { SRPD }\end{array}$ & $\begin{array}{l}0 \\
\text { SRPC }\end{array}$ \\
\hline 1 MÉTODO & & & & \\
\hline JUL/92 & $83,4 \mathrm{aDE}$ & $52,0 \mathrm{cDE}$ & $122,5 \mathrm{aB}$ & $59,4 \mathrm{CF}$ \\
\hline JAN/93 & $128,8 \mathrm{bB}$ & $70,7 \mathrm{cB}$ & $192,1 \mathrm{aB}$ & $82,5 \mathrm{cBC}$ \\
\hline MAR/93 & $178,8 \mathrm{bA}$ & $99,1 \mathrm{dA}$ & $225,5 \mathrm{aA}$ & $124,7 \mathrm{CA}$ \\
\hline MAI/93 & $105,0 \mathrm{bCD}$ & $74,7 \mathrm{CCD}$ & $137,6 \mathrm{aB}$ & $70,8 \mathrm{CEF}$ \\
\hline MAI/93 & $119,7 \mathrm{bBC}$ & $61,5 \mathrm{CBC}$ & $175,5 \mathrm{aB}$ & $77,1 \quad \mathrm{CCD}$ \\
\hline JUL/93 & $65,5 \mathrm{bE}$ & $67,4 \mathrm{bE}$ & $130,5 \mathrm{aB}$ & $54,8 \mathrm{bEF}$ \\
\hline OUT/93 & $102,0 \mathrm{bCD}$ & $57,5 \mathrm{cCD}$ & $154,1 \mathrm{aB}$ & $70,2 \mathrm{CDE}$ \\
\hline JAN/94 & $140,9 \mathrm{bB}$ & $67,2 \mathrm{~dB}$ & $214,4 a B$ & $91,6 \mathrm{CAB}$ \\
\hline 2 MÉTODO & & & & \\
\hline JUL/92 & $83,6 \mathrm{bD}$ & $55,3 \mathrm{cB}$ & $114,0 \mathrm{aB}$ & $69,1 \mathrm{bcBC}$ \\
\hline JAN/93 & $133,5 \mathrm{bAB}$ & $76,1 \mathrm{CAB}$ & $171,5 \mathrm{aA}$ & $80,2 \mathrm{cB}$ \\
\hline $\mathrm{MAR} / 93$ & $148,3 \mathrm{bA}$ & $82,3 \mathrm{dA}$ & $172,5 \mathrm{aA}$ & $111,2 \mathrm{cA}$ \\
\hline MAI / 93 & $95,7 \mathrm{bCD}$ & $60,0 \mathrm{CAB}$ & $132,0 \mathrm{aB}$ & $71,1 \mathrm{cBC}$ \\
\hline $\mathrm{MAI} / 93$ & $121,1 \mathrm{aB}$ & $66,3 \mathrm{bAB}$ & $138,5 \mathrm{aB}$ & $79,9 \mathrm{bBC}$ \\
\hline JUL/93 & $72,8 \mathrm{bD}$ & $62,3 \mathrm{bcAB}$ & $117,3 \mathrm{aB}$ & $51,2 \mathrm{CC}$ \\
\hline OUT/93 & $87,3 \mathrm{bD}$ & $66,7 \mathrm{CAB}$ & $116,3 \mathrm{aB}$ & $50,0 \mathrm{cC}$ \\
\hline JAN / 94 & $115,3 \mathrm{bBC}$ & $62,8 \mathrm{dAB}$ & $169,0 \mathrm{aA}$ & $85,1 \mathrm{cB}$ \\
\hline 3 MÉTODO $^{\square}$ & & & & \\
\hline JUL/92 & $133,5 \mathrm{bB}$ & $85,0 \mathrm{cA}$ & $169,5 \mathrm{aAB}$ & $101,1 \mathrm{CA}$ \\
\hline $\mathrm{MAR} / 93$ & $167,8 \mathrm{aA}$ & $70,0 \quad \mathrm{CABC}$ & $178,7 \mathrm{aA}$ & $106,2 \mathrm{bA}$ \\
\hline $\mathrm{MAI} / 93$ & $133,8 \mathrm{bB}$ & $74,0 \quad \mathrm{CABC}$ & $156,8 \mathrm{aB}$ & $88,3 \mathrm{CAB}$ \\
\hline $\mathrm{MAI} / 93$ & $130,8 \mathrm{bB}$ & $62,3 \mathrm{cBC}$ & $157,7 \mathrm{aB}$ & $71,0 \quad \mathrm{cBC}$ \\
\hline JUL/93 & $117,7 \mathrm{aB}$ & $61,2 \mathrm{cC}$ & $163,2 \mathrm{aAB}$ & $67,2 \mathrm{cC}$ \\
\hline OUT/93 & $127,3 \mathrm{bB}$ & $81,1 \quad C A B$ & $162,3 \mathrm{aAB}$ & $61,5 \mathrm{cC}$ \\
\hline
\end{tabular}

* médias seguidaa de mesma letra maiúscula, na vertical, não diferem significativamente entre si; médias seguidas de mesma letra minúscula, na horizontal, năo diferem significativamente entre si. $\quad \square$ o teste de Tukey foi feito dentro de um mesmo método de de incubação de solo. 
No geral, para as três variantes do método de incubação do solo para a determinação de biomassa microbiana foi verificado que não houve diferença significativa entre $\circ$ método 1 e o método 2 (coeficiente de correlação $r=0.91 * *$ ). Esses resultados são coerentes, pois a única diferença entre eles foi o tempo de armazenamento ao qual o solo foi submetido previamente à incubação; sendo que as amostras de solo nesses métodos foram incubados com a umidade original de campo. Este resultado é importante porque demonstra que é perfeitamente viável estocar-se amostras de solo por períodos superiores a 20 dias antes de se proceder à determinação da biomassa, sem acarretar diferenças nos resultados. Frequentemente, o pesquisador se vê numa situação em que é obrigado a estocar as amostras, pela impossibilidade de trabalhá-las imediatamente após a sua coleta, quer seja pelo número excessivo de amostras, quer seja pela distância e tempo decorrido até a sua chegada ao laboratório. Como não se encontraram informações sobre estocagem de amostras de solo para fins de determinação de biomassa microbiana na literatura, foi considerada essencial a verificação acima descrita, o que viria a facilitar os procedimentos para pesquisadores que estivessem impossibilitados de incubar as amostras num período de 48 horas, conforme é preconizado no método de JENKINSON \& POWLSON, 1976.

Sabe-se que os valores obtidos para quantificação da biomassa microbiana obtidos por diferentes autores é extremamente variável. PAVAN (1991) encontrou valores de $51 \mu \mathrm{g} \mathrm{C}-\mathrm{CO}_{2} / \mathrm{g}$ de solo em latossolo vermelho escuro textura média para o cultivo de eucalipto; enquanto que FIEGL (1994) chegou a obter valores tão altos como de $1009 \mu \mathrm{g} \mathrm{C}-\mathrm{CO}_{2} / \mathrm{g}$ de solo para 
ossixol sob pastagem, não existindo na literatura classificação da biomassa em teores alto, médio ou baixo. O processo da fumigação do solo pode estar influindo nas variações citadas acima, pois por problemas diversos de ordem química e física do solo, pode em alguns solos não estar havendo a recolonização total do solo fumigado durante os 10 dias de incubação. Tanto não recolonização quanto até mesmo a não ocorrência da morte da maioria da comunidade microbiana durante a fumigação pode afetar sobremaneira a determinação da biomassa. O método da fumigaçãoextração é um método bastante utilizado para solo com baixo pH e devido a não ter o processo de incubação; pois $O C$ é extraido após fumigação pode talvez resultar em menores oscilações de valores; alguns autores como GERALDES (1993), observaram que o método fumigação-extração apresentou valores bem mais constantes e com menores oscilações do que a fumigação incubação. No presente estudo o método fumigaçãoincubação apresentou valores com peqenas oscilações (desvio padrão variando desde 9.6 até $37.6 \%$ ). O fator Kc (coeficiente de mineralização) foi determinado inicialmente para solos de clima temperado (JENKINSON \& POWLSON, 1976) e até hoje é utilizado para calcular a biomassa microbiana. Esse valor provavelmente não deve ser o mesmo para todos os tipos de solos, havendo necessidade de se estimar esse coeficiente para diversos solos no Brasil e verificar se o coeficiente 0.45 seria de fato o melhor valor. Outro valor bastante utilizado por inumeros autores para o coeficiente de mineralização é 0.41 .

Para 0 método 3, houve diferença significativa, quando comparado aos método 1 e 2 somente para as épocas de julho/92 e julho/93. 
Observou-se que nesses meses houve os menores índices de precipitação, cerca de $12 \mathrm{~mm}$ (Tabela 3). Portanto, o solo encontrava-se extremamente seco refletindo também menores teores de umidade em que o solo foi incubado para a avaliação da biomassa (Tabela 4). Como a diferença do método 3 está em que o solo foi elevado a 50\% da c.C. e armazenado a $4^{\circ} \mathrm{C}$ por 15 dias, a comunidade microbiana do solo deve ter respondido ao umidecimento, mesmo estando à temperatura de $4^{\circ} \mathrm{C}$. Para as outras épocas, o teor de umidade do solo não se apresentava limitante ao desenvolvimento da comunidade microbiana, está foi semelhante para os tres métodos em estudo. Com isto, verifica-se que, no momento de coleta do solo a campo, a biomassa microbiana apresetava-se praticamente igual aquela em que o solo foi elevado a 50\% c.c., isso só foi possível devido a já existir um teor de umidade no solo alto. Em algumas épocas, o teor de umidade do solo passava de 50\% da c.c., o que foi verificado no meses de janeiro/93 e 94 (Tabela 3), portanto a umidade em que o solo é incubado afeta a biomassa se compararmos com a umidade ideal que 0 método da fumigação-incubação recomenda (50\% da c.c.). Ainda assim, foi obtido um coeficiente médio de correlạção entre o método 3 e os métodos 1 e 2 de $0.87^{*}$.

\subsection{Atividade da desidrogenase do solo}

Usou-se o método de CASIDA Jr. (1964), que se constitui na maneira clássica e rotineira mesmo nos dias atuais para a determinação da atividade de desidrogenase. Para tanto foi preciso estabelecer-se 
uma curva padrão para a redução de trifeniltetrazólio para trifenilformazana. A curva de calibração no presente estudo esta apresentada na Figura 1 com coeficiente de regressão $r^{2}=0.95^{\star *}$. Verificou-se que a atividade de desidrogenase foi decrescendo com $\circ$ aumento da profundidade e que, nos $5 \mathrm{~cm}$ superiores do solo a atividade da desidrogenase era significativamente maior no solo sob plantio direto (Tabela 11). Essa mesma tendência foi observada para a biomassa microbiana do solo, embora, no caso dessa última, também se encontraram diferenças a maiores profundidades. Autores COMO DORAN (1984) e BOLTON et al. (1985) também observaram essa tendência da atividade de desidrogenase em acompanhar a biomassa microbiana. De fato, esses resultados eram esperados, uma vez que o teor de C orgânico do solo bem como $\circ$ acúmulo de nutrientes (Tabela 5 e 6), criam um ambiente onde o crescimento microbiano e sua atividade podem ser grandemente estimulados. Assim, o substrato residual associado ao sistema de preparo de solo pode influi nos tipos de microrganismos que vão predominar e consequentemente, irá refletir na atividade de desidrogenase, visto que esta pode ser considerada como medida da atividade metabólica total da comunidade microbiana viável, existindo somente na parte integral de células intactas. Neste ponto, a desidrogenase se diferencia de outros enzimas do solo que podem participar de reações bioquímicas, mesmo quando excretadas por células vivas ou liberadas por células lisadas. 


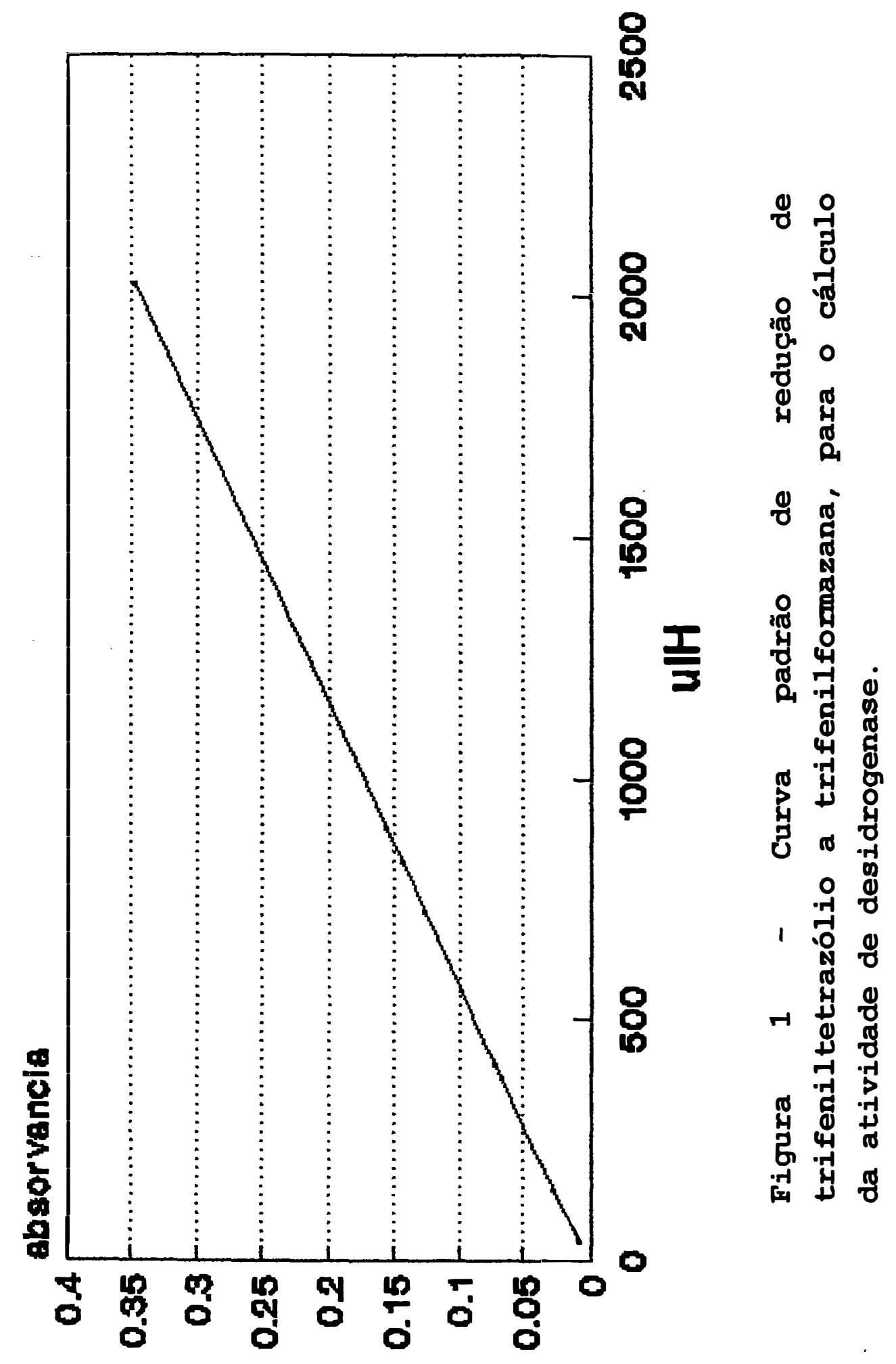


Tabela 11 - Desdobramento, pelo teste de Tukey, da interação manejo do solo $x$ profundidade de amostragem para a atividade de desidrogenase.

\begin{tabular}{|c|c|c|c|c|}
\hline $\begin{array}{l}\text { PROFUNDIDADE } \\
(\mathrm{cm})\end{array}$ & $\begin{array}{l}------1 \\
\text { SCPD }\end{array}$ & $\begin{array}{l}\text { DESIDI } \\
--(\mu l \mathrm{H} / \mathrm{g} \\
\mathrm{SCPC}\end{array}$ & $\begin{array}{l}\text { GENASE } \\
\text { SOlO) } \\
\text { SRPD }\end{array}$ & SRPC \\
\hline $0-5$ & 95,33 aA & $63,20 \mathrm{bA}$ & $106,56 \mathrm{aA}$ & $52,30 \mathrm{bA}$ \\
\hline $5-10$ & $47,59 \mathrm{aB}$ & $38,01 \mathrm{aB}$ & $56,02 \mathrm{aB}$ & $35,06 \mathrm{aB}$ \\
\hline $10-20$ & $29,50 \mathrm{aC}$ & $19,72 \mathrm{aC}$ & $32,33 \mathrm{aC}$ & $16,68 \mathrm{aC}$ \\
\hline
\end{tabular}

A determinação da atividade de desidrogenase foi realizada somente em três épocas (julho/93, outubro/93 e janeiro/94), apresentando diferenças acentuadas entre essas, ou seja, a atividade de desidrogenase foi menor para a época de julho/93 do que para as demais épocas. Esse fato pode ser explicado pela observação de que nessas épocas as condições climáticas, principalmente precipitação foram diferentes, isto é, em julho/93 houve uma baixa precipitação, quando comparada aos meses de outubro e janeiro (Tabela 3). Também ocorreram diferenças significativas entre os valores para biomassa dessas três épocas (Tabela 10). 
Tabela 12 - Desdobramento, pelo teste de Tukey, da interação manejo de solo x épocas de amostragem para o parâmetro desidrogenase do solo.

\begin{tabular}{|c|c|c|c|c|}
\hline $\begin{array}{c}\text { ÉPOCAS } \\
D E\end{array}$ & $-\ldots----$ & $\begin{array}{l}\text { DESIDROGE } \\
--(\mu \mathrm{H} / \mathrm{g}\end{array}$ & $\begin{array}{l}\text { ASE DO SO } \\
\text { e solo) }\end{array}$ & ---------- \\
\hline AMOSTRAGEM & SCPD & SCPC & SRPD & SRPC \\
\hline JUL/93 & 43,52 aB & $33,47 \mathrm{bB}$ & 53,06 aB & $29,47 \mathrm{bB}$ \\
\hline OUT / 93 & 54,73 aA & $36,82 \mathrm{bA}$ & $68,93 \mathrm{aA}$ & $36,42 \mathrm{bA}$ \\
\hline JAN/94 & $58,16 \mathrm{bA}$ & $37,73 \mathrm{cA}$ & 72,91 aA & $36,16 \mathrm{CA}$ \\
\hline
\end{tabular}

Para uma mesma época de amostragem, O PD também foi sempre superior ao PC (Tabela 12), resultado este que mostra tendência semelhante à da flutuação da biomassa (Tabela 10).

Considerando-se as três variantes de incubação para a determinação de biomasssa microbiana utilizadas neste trabalho, a atividade de desidrogenase mostrou uma correlação estreita ao nível de 1\% de probabilidade com todas elas. O coeficiente de correlação médio foi 0,86 e a curva de regressão foi y $=2,6+1,9 \mathrm{x}$. SKUJINS (1973); CASIDA Jr. (1977); DORAN (1980); FRANKESBERGER \& DICK (1983) e DICK (1988a) observaram também correlação estreita entre a biomassa e atividade de desidrogenase.

Portanto, foi possível estimar a biomassa microbiana através da atividade da desidrogenase, o que é interessante em virtude de se tratar de uma técnica muito mais simples e rápida do que a determinação da biomassa microbiana. 


\subsection{Micorriza}

\subsubsection{Porcentagem de colonização endomicorrízica}

Para aveia preta, verificou-se que, na primeira amostragem, a porcentagem de colonização micorrízica foi influenciada pelo sistema de rotação de culturas, onde a SC foi superior à SR (Tabela 13). Não houve, no entanto, influência do tipo de preparo do solo sobre este parâmetro. Para a segunda amostragem de raiz a porcentagem de colonização não diferiu para os diferentes sistemas de manejo de solo. Para a cultura de aveia a porcentagem de colonização endomicorrízica foi relativamente alta. Diversos trabalhos que estudam a colonização a campo das mais variadas culturas apresentaram dados bastante discrepantes entre si; encontrando-se colonização endomicorrizica variando desde 0\% (CASTRO et al., 1993 e COSTA \& BONONI, 1991) até 90\% (TRUFEM et al.,1989), sendo variável quantativamente e qualitativamente de acordo com os agro e ecossistema. Considerando-se os valores elevados de $\mathrm{P}$ encontrados neste solo (Tabela 6), pode-se considerar que esta porcentagem de micorrização foi até bastante elevada. Foi observado para a cultura de aveia a presença de arbusculos dentro das raizes infectadas e pouquíssimas vezes a presença de vesícula; este fato indica que a maioria dos fungos $M A$ que colonizaram a aveia pertencem ao gênero Scuttlospora ou Gigaspora, pois são os únicos gêneros que formam arbúsculos dentro de raizes infectadas.

A amostragem de raiz de soja foi feita no dia 25/03/93. Os resultados demonstraram 
praticamente a inexistência de colonização das raizes por fungos endomicorrízicos, discrepando totalmente dos resultados encontrados para aveia. CASTRO et al., (1993), num experimento de casa de vegetação, porém utilizando o mesmo solo deste trabalho, observaram resultados semelhantes. Estes autores levantaram a hipótese de que o alto teor de $\mathrm{P}$ tenha sido responsável pela quase ausência de micorrização. A mesma consideração poderia ser feita para $\circ$ presente trabalho. O fato de que a soja não apresentou formação de micorriza, embora a aveia tenha uma colonização radicular bastante razoável, pode demonstrar mais uma vez que cada sistema composto de hospedeiro-endófitosolo reage de uma maneira diferenciada, não se podendo fazer generalizações.

Nessa cultura foi efetuada antes do plantio $\circ$ tratamento de semente com 0 produto comercial Tecto 100 na dose $200 \mathrm{~g} / 100 \mathrm{~kg}$ de semente, que é um fungicida sistêmico do grupo dos benzimidazois da classe toxicológica IV (ROCHA, 1993), sendo este compatível com a sobrevivência da bactéria fixadora de nitrogênio (Bradyrhizobium japonicum) na semente segundo, a OCEPAR/EMBRAPA-CNPSo (1994); entretanto, não foi encontrado nehuma referência sobre o efeito desse fungicida sobre os fungos MA. Seria lícito, portanto, especular que talvez a presença deste fungicida tenha sido deletéria para o fungo, impedindo a colonização das raizes; sugerindo que sejam realizadas mais pesquisas sobre o efeito de fungicidas na colonização endomicorrizica por fungos MA. 
Tabela 13 - Porcentagem de colonização endomicorrízica na cultura de aveia preta (média de seis repetições por parcela).

\begin{tabular}{|c|c|c|}
\hline TRATAMENTOS & $\begin{array}{l}\text { PORCENTAGEM } \\
\text { PRIMEIRA AMOSTRAGEM } \\
(25 / 10 / 92)\end{array}$ & $\begin{array}{c}\text { COLONIZAÇÃO } \\
\text { SEGUNDA AMOSTRAGEM } \\
(20 / 07 / 93)\end{array}$ \\
\hline SCPD & $41,08 \quad a b$ & $34,09 \quad a$ \\
\hline SCPC & 43,55 & $35,07 \quad a$ \\
\hline SRPD & $37,81 \quad \mathrm{ab}$ & 36,37 \\
\hline SRPC & $34,66 \quad b$ & 36,25 \\
\hline $\mathrm{CV} \quad(\%)$ & 20,27 & 19,40 \\
\hline $\mathrm{PD}$ & $41,24 \quad \mathrm{~A}$ & $34,82 \quad \mathrm{~A}$ \\
\hline $\mathrm{PC}$ & $44,86 \quad \mathrm{~A}$ & $36,31 \quad \mathrm{~A}$ \\
\hline $\mathrm{CV} \quad(\%)$ & 13,05 & 7,4 \\
\hline SC & $49,88 \quad \beta$ & $35,29 \quad \alpha$ \\
\hline$S R$ & $36,23 \alpha$ & $34,08 \quad \alpha$ \\
\hline $\mathrm{CV} \quad(\%)$ & 28,55 & 8,29 \\
\hline
\end{tabular}

Segundo LOPES et al.(1983a) existem vários fatores que afetam as micorrizas $V A$, como os fatores do solo: químico, físico e biológico; agroquímicos, manejo do solo, cultura e fatores genéticos. De acordo com MENGE (1982) os fungicidas sistêmicos podem reduzir ou inibir a colonização das raizes; já SILVEIRA (1992) relata que os fungicidas sistêmicos inibem os fungos $M A$ agindo nas estruturas dos fungos, mas podendo também eliminá-lo dentro dos tecidos colonizados. A soja tratada com 0 fungicida sistêmico Tecto 100 não apresentou colonização 
endomicorrizica por fungos $\mathrm{MA}$, enquanto a aveia preta, que não havia recebido nenhum tratamento fungicida, cultivada nesse mesmo solo, no inverno, apresentou colonização endomicorrízica variando desde $34 \%$ até $50 \%$.

No geral a porcentagem de colonização endomicorrízica não evidenciou influência dos diferentes tratamentos, embora tenham sido encontrados efeitos sobre alguns parâmetros químicos e biológicos.

\subsubsection{Fungos MA}

- número de esporos a diferentes profundidades, diferentes manejos do solo e diferentes épocas de amostragem foram baixos, variando de 4 a 11 esporos/50 $\mathrm{ml}$ de solo. Entretanto, em todas essas épocas foram encontrados de 40 a 61 esporos vazios/50ml de solo, provavelmente remanescentes de esporos já germinados.

Os diferentes tipos de manejo e profundidade não afetaram $\circ$ número de esporos, mas este foi afetada pela época. Alguns autores como SILVEIRA (1992) e LOPES et al. (1983ab) comentam sobre o efeito do tipo de manejo de solo sobre multiplicação de esporos.

Para o número de esporos (cheios e vazios) houve uma tendência para os meses mais frios e secos (maio, julho/92 e 93) apresentarem maiores números, quando comparado com os meses mais quentes $e$ pluviosos (janeiro, março e outubro) (Tabela 14). Na amostragem de maio/93 ocorreu a colheita da soja, obtendo-se o maior número de esporos cheios/50 $\mathrm{ml}$ de solo; março/93 foi o florescimento da soja e janeiro/94 
o plantio da soja observando os menores números de esporos cheios $/ 50 \mathrm{ml}$ de solo. Esses resultados vêm ao encontro de BONONI et al. (1988), para os quais a multiplicação de esporos de fungos MA estaria relacionada com o final do ciclo da cultura. Não foram observados esses aspectos para a cultura da aveia preta.

Tabela 14 - Número de esporos cheios e esporos vazios para diferentes épocas de amostragens de solo, na região de Campinas/SP.

\begin{tabular}{|c|c|c|}
\hline ÉPOCAS & $\begin{array}{r}\text { MÉDIA DE } \\
\text { CHEIOS } \\
\end{array}$ & $\begin{array}{c}50 \mathrm{ml} \text { DE SOLO } \\
\text { VAZIOS } \\
\end{array}$ \\
\hline julho/92 & $5,71 \quad b$ & $46,11 \quad a b c$ \\
\hline janeiro/93 & 4,71 & $39,69 \mathrm{cb}$ \\
\hline março/93 & 4,04 & $31,14 \mathrm{c}$ \\
\hline maio/93 & $11,09 \mathrm{a}$ & $61,46 \quad a$ \\
\hline maio/93 & 7,08 & $49,71 \mathrm{ba}$ \\
\hline julho/93 & 5,02 & $66,91 \quad a$ \\
\hline outubro/93 & 4,98 & $40,45 \quad b c$ \\
\hline janeiro/94 & 3,99 & $37,21 \quad b c$ \\
\hline
\end{tabular}

Dificilmente se pode considerar que esse incremento de esporos tivesse ocorrido na cultura da soja, visto que a mesma não apresentou colonização endomicorriza e o fungo MA, para multiplicação, necessita obrigatoriamente de um hospedeiro. No experimento, durante a condução da soja, foi observada a ocorrência de plantas daninhas. Talvez o fungo MV possa tê-las utilizado para multiplicação. Entretanto, 
não foi avaliada a porcentagem de colonização micorrizica nestas plantas.

Existem outras variáveis que poderiam estar relacionadas com a variação no número de esporos durante a condução do presente estudo, como temperatura, luz, aeração e umidade do solo que afetam - grau de colonização, formação de arbuscúlos, esporulação e resposta do hospedeiro (MOSSE et al., 1981; LOPES et al., 1983a; MENGE, 1982 e SILVEIRA, 1992), entretanto, estas não foram avaliadas.

Os gêneros e as espécies identificadas foram: Scutellospora gregaria, Scutellospora sp., Acaulospora scrobiculata, Acaulospora sp., Gigaspora sp. e Glomus sp.; sendo que a identificação da espécie Scutellospora gregaria foi confirmada por MORTON, $1994^{1}$ - Entre todas as espécies, a que se destacou sobremaneira foi a Scutellospora gregaria, que estava presente em todas as amostras (Tabela 15).

TRUFEM et al. (1989) mencionam que os solos tropicais são ricos em espécies de Acaulospora e Scutellospora, em contraposição aos solos de regiões temperadas, onde predominam as espécies de Glomus (MOSSE et al., 1981 e SIQUEIRA \& FRANCO, 1988). Autores como TRUFEM et al. (1990) e BONONI et al. (1988) encontraram o gênero Scutellospora no Estado de São Paulo na região de Mogi-Guaçu e no jardim Botânico, mas não evidenciaram a espécie $S$. gregaria. MAIA \& TRUFEM (1990) observaram a ocorrência de scutellospora gregaria em Pernambuco em larga faixa de níveis de $\mathrm{P}$ (variando de 4-30 ppm), tendo boa distribuição entre pH 5 e 6,1, dados esse que corroboram com os dados obtidos no presente trabalho. Resultados encontrados nesse

1 MORTON, 1994 (Comunicação Pessoal). 


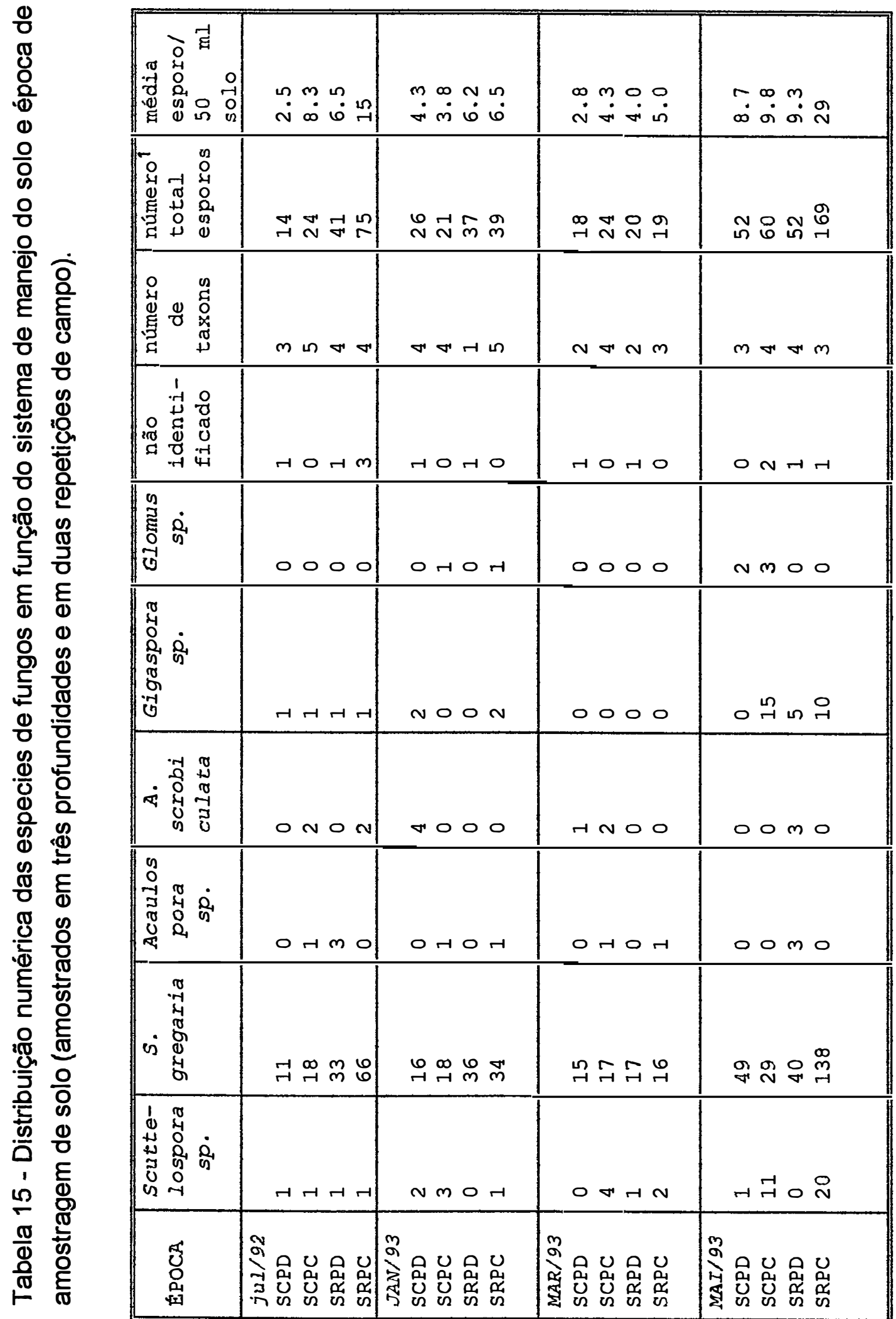




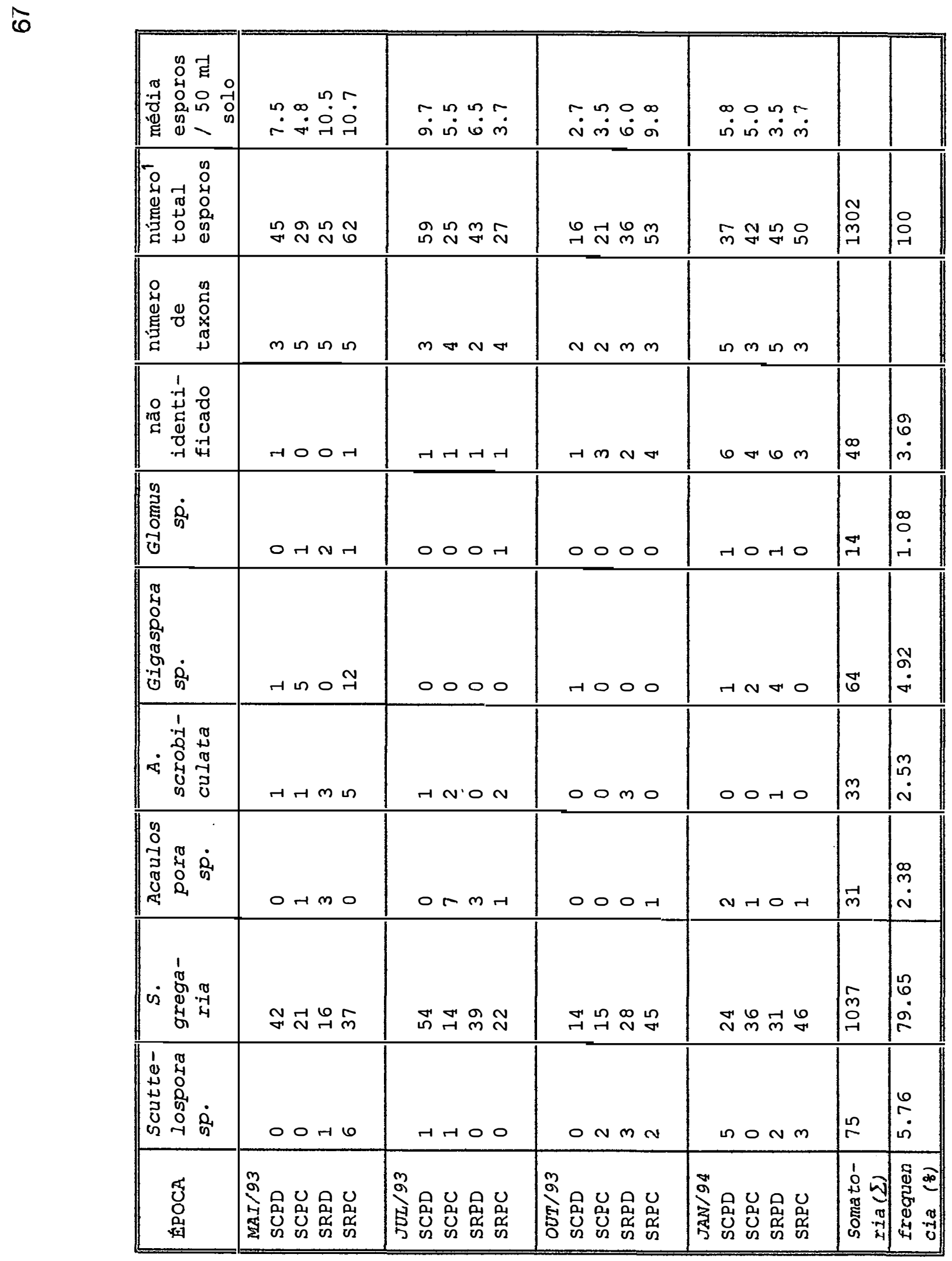


trabalho corroboram autores que verificaram a predominância de Gigaspora comuns em solos tropicais (MOSSE et al., 1981); pois nesta época Scutellospora era denominada de Gigaspora (WALKER \& SANDERS, 1986).

\subsection{Rizóbio}

Observa-se na Tabela 16, que o número de nódulos foi superior no tratamento SRPD do que no SRPC, ficando os outros dois tratamentos intermediários. Os dados de nodulação no campo foram baixos, com nódulos em geral pequenos, mas apresentaram em sua maioria cor rósea, indicando fixação eficiente. Vários fatores poderiam estar envolvidos nesta baixa nodulação observada. A temperatura, o teor de nitrogênio do solo, stress hídrico, entre outros, afetam substancialmente a nodulação e fixação do nitrogênio, segundo MALER \& WOLLUM, 1980; VOSS \& SIDIRAS, 1985 e VIDOR et al., 1987.

É sabido que o plantio direto afeta as condições de umidade, temperatura e nitrogênio do solo quando comparado com plantio convencional, podendo favorecer o desenvolvimento do rizóbio sob plantio direto (CASTRO et al., 1993; VOSS \& SIDIRAS, 1985 e MUZILLI, 1983). Neste caso as condições climáticas (Tabela 3) durante a condução da cultura da soja foi favorável ao desenvolvimento do rizóbio, pois nos meses de janeiro/93 (plantio da soja) a março/93 (florescimento da soja) a temperatura máxima foi de $34.6^{\circ} \mathrm{C}$ e teve boa precipitação; $\mathrm{o} \mathrm{pH}$ do solo estava adequado para o cultivo da soja (Tabela 5); os teores 
Tabela 16 - Número de nódulos e matéria seca dọs nódulos e raizes para a cultura da soja, no início do florescimento (amostragem realizada dia 25/03/93).

\begin{tabular}{|c|c|c|c|}
\hline \multirow[t]{2}{*}{$\begin{array}{l}\text { MANEJO DO } \\
\text { SOLO }\end{array}$} & \multirow[t]{2}{*}{$\begin{array}{l}\text { NÚMERO DE } \\
\text { NÓDULOS }\end{array}$} & \multicolumn{2}{|c|}{$\begin{array}{l}\text { MATÉRIA SECA } \\
-\end{array}$} \\
\hline & & NÓDULOS & RAIZES \\
\hline SCPD & $6,46 \mathrm{ab}$ & $0,37 \mathrm{a}$ & $1,40 \mathrm{a}$ \\
\hline SCPC & $6,66 \mathrm{ab}$ & $0,38 \quad a$ & $1,48 \quad a$ \\
\hline SRPD & $6,74 \quad a$ & $0,34 \quad a$ & 1,62 a \\
\hline SRPC & 5,12 & $0,26 \mathrm{a}$ & 1,56 a \\
\hline $\mathrm{CV} \quad\left(\frac{\circ}{0}\right)$ & 30,7 & 27,20 & 19,28 \\
\hline $\mathrm{PC}$ & 5,81 & $0,31 \mathrm{~A}$ & $1,50 \mathrm{~A}$ \\
\hline $\mathrm{PD}$ & 6,68 & $0,36 \mathrm{~A}$ & $1,52 \mathrm{~A}$ \\
\hline$\left(\frac{0}{0}\right)$ & 23,01 & 30,07 & 20,28 \\
\hline $\mathrm{SC}$ & $39,79 \quad \beta$ & $0,33 \beta$ & $1,46 \beta$ \\
\hline SR & 45,75 & $0,42 \beta$ & $1,63 \beta$ \\
\hline $\mathrm{CV} \quad(\%)$ & 18,75 & 24,44 & 10,56 \\
\hline
\end{tabular}

* médias seguidas de mesma letra nas três comparações, na vertical, não diferem significativamente entre si.

de $\mathrm{N}$ encontrados não são considerados prejudiciais, pois, foi considerado para esse solo um teor médio de $\mathrm{N}$ e na literatura há relatos que teores altos de $\mathrm{N}$ poderiam prejudicar o desenvolvimento dos nódulos (Tabela 7); a estirpe de rizóbio utilizada foi do IAC, adequada as condições ambientais do local; o teor de $\mathrm{P}$ nesse solo (Tabela 6) foi considerado alto no plantio da soja, porém não prejudicial para o rizóbio(FREIRE et al., 1983; SAITO et al., 1983; VOSS \& SIDIRAS, 1985; VIDOR et al., 1987; MOROTE et al., 1990; FREIRE, 1992 ;CASTRO et al., 1993;). Entretanto, pode-se que em algum momento tivesse ocorrido condições de anaerobiose no solo, pois em janeiro houve uma alta precipitação, 
este poderia ter afetado o desenvolvimento do rizobio, pois, a bactéria é aeróbica.

Os dados apresentados aqui não concordam com os resultados obtidos por VOSS \& SIDIRAS, 1984 e CASTRO et al., 1993 que observaram uma superioridade do plantio direto no que se refere a nodulação da soja.

\subsection{Teores de nutrientes da parte aérea}

$\mathrm{Na}$ cultura de aveia preta e soja o teor de nitrogênio $(\mathrm{N})$ da parte aérea no início de florescimento (Tabelas 17, 18 e 19), mostraram que este diferiu significativamente para os diferentes tratamentos, onde houve uma superioridade deste teor nos tratmentos sob plantio convencional (SCPC e SRPC). Essa superioridade do teor de $\mathbf{N}$ na planta sob preparo convencional em relação ao plantio direto já era esperado, pois no sistema de plantio direto há uma menor disponibilidade de $\mathrm{N}$, pois há uma menor taxa de mineralização da matéria orgânica que resulta em menor disponibilidade de $\mathrm{N}$ no solo. Resultados semelhantes foram obtidos por THOMAS, 1980 e MUZILLI, 1983. 
Tabela 17 - Nutrientes da parte aérea da cultura de aveia preta coletada no início de florescimento (25/10/92).

\begin{tabular}{|c|c|c|c|c|c|c|c|}
\hline \multirow{2}{*}{ NUTRIENTES } & \multicolumn{6}{|c|}{ TRATAMENTOS } & \multirow{2}{*}{$\begin{array}{l}\mathrm{CV} \\
\left(\frac{0}{0}\right)\end{array}$} \\
\hline & \multicolumn{2}{|c|}{ SCPD } & SCPC & \multicolumn{2}{|c|}{ SRPD } & SRPC & \\
\hline$N(g / k g)$ & 1,65 & $\mathrm{bc}$ & $1,96 \quad a$ & 1,49 & $\mathrm{C}$ & $1,89 \quad \mathrm{ab}$ & 10,17 \\
\hline $\mathrm{P} \quad(\mathrm{g} / \mathrm{kg})$ & 0,22 & $a$ & $0,19 \mathrm{~b}$ & 0,21 & $a$ & $0,19 \quad b$ & 7,13 \\
\hline$K(g / k g)$ & 3,07 & $\mathrm{a}$ & $3,05 \quad a$ & 2,92 & $\mathrm{a}$ & 2,81 & 6,50 \\
\hline $\mathrm{Ca}(\mathrm{g} / \mathrm{kg})$ & 0,78 & $\mathrm{a}$ & 0,79 & 0,91 & $\mathrm{a}$ & 0,80 & 22,19 \\
\hline $\operatorname{Mg}(\mathrm{g} / \mathrm{kg})$ & 0,25 & $\mathrm{a}$ & 0,20 & 0,26 & $\mathrm{a}$ & 0,23 & 5,97 \\
\hline $\mathrm{Zn} \quad(\mathrm{mg} / \mathrm{kg})$ & 14.83 & $\mathrm{a}$ & $15,17 \quad$ & 15,67 & $\mathrm{a}$ & $14,50 \mathrm{a}$ & 8,09 \\
\hline $\mathrm{Cu} \quad(\mathrm{mg} / \mathrm{kg})$ & 4,83 & $\mathrm{a}$ & $4,67 \quad$ & 5,33 & $a$ & $5,83 \quad a$ & 29,51 \\
\hline $\mathrm{Fe} \quad(\mathrm{mg} / \mathrm{kg})$ & 540,0 & $\mathrm{a}$ & 382,0 & 560,2 & $\mathrm{a}$ & $530,2 \quad a$ & 36,97 \\
\hline Mn $(\mathrm{mg} / \mathrm{kg})$ & 139,3 & $a$ & 171,2 & 139,8 & $a$ & $139,7 \mathrm{a}$ & 11,03 \\
\hline $\mathrm{S} \quad(\mathrm{g} / \mathrm{kg})$ & 0,19 & $\mathrm{a}$ & 0,17 & 0,18 & $\mathrm{a}$ & $0,18 \quad a$ & 11,52 \\
\hline
\end{tabular}


Tabela 18 - Nutrientes da parte aérea da cultura de soja coletada no início de florescimento (25/03/93).

\begin{tabular}{|c|c|c|c|c|c|c|c|c|}
\hline \multirow{3}{*}{$\begin{array}{l}\text { NUTRIENTES } \\
N \quad(\mathrm{~g} / \mathrm{kg})\end{array}$} & \multicolumn{7}{|c|}{ TRATAMENTOS } & \multirow{3}{*}{$\begin{array}{r}\text { CV } \\
(\%)\end{array}$} \\
\hline & \multicolumn{2}{|c|}{ SCPD } & SCPC & \multicolumn{2}{|c|}{ SRPD } & \multicolumn{2}{|c|}{ SRPC } & \\
\hline & 2,35 & $\mathrm{~b}$ & $2,60 \quad a$ & 2,11 & $\mathrm{~b}$ & 2,60 & $\mathrm{a}$ & \\
\hline$P \quad(g / k g)$ & 0,21 & $a$ & 0,18 & 0,19 & $a b$ & 0,16 & $\mathrm{C}$ & 13,16 \\
\hline $\mathrm{K}(\mathrm{g} / \mathrm{kg})$ & 2,02 & $a$ & 1,86 & 1,90 & $a$ & 1,88 & $a$ & 6,93 \\
\hline $\mathrm{Ca}(\mathrm{g} / \mathrm{kg})$ & 1,90 & $a b$ & 1,86 & 1,96 & a & 1,75 & b & 6,28 \\
\hline $\mathrm{Mg} \quad(\mathrm{g} / \mathrm{kg})$ & 0,53 & $\mathrm{~b}$ & 0,53 & 0,65 & $\mathrm{a}$ & 0,54 & $\mathrm{~b}$ & 9,27 \\
\hline $\mathrm{Zn} \quad(\mathrm{mg} / \mathrm{kg})$ & 29,17 & $\mathrm{a}$ & $24,33 \mathrm{a}$ & 18,83 & $\mathrm{a}$ & 20,50 & $\mathrm{a}$ & 31,53 \\
\hline $\mathrm{Cu} \quad(\mathrm{mg} / \mathrm{kg})$ & 8,50 & $\mathrm{a}$ & $6,17 \quad a$ & 6,67 & $a$ & 10,33 & $a$ & 30,32 \\
\hline $\mathrm{Fe} \quad(\mathrm{mg} / \mathrm{kg})$ & 987,3 & $\mathrm{a}$ & $624,2 \mathrm{a}$ & 617,0 & $a$ & 851,5 & $a$ & 29,51 \\
\hline $\mathrm{Mn} \quad(\mathrm{mg} / \mathrm{kg})$ & 49,5 & $\mathrm{a}$ & $43,33 \mathrm{a}$ & 44,00 & $a$ & 45,67 & $a$ & 10,07 \\
\hline$S(\mathrm{~g} / \mathrm{kg})$ & 0,17 & $\mathrm{a}$ & 0,18 & 0,15 & $a$ & 0,15 & $\mathrm{a}$ & 22,43 \\
\hline
\end{tabular}


Tabela 19 - Nutrientes da parte aérea da cultura de aveia preta coletada no início de florescimento $(20 / 07 / 93)$.

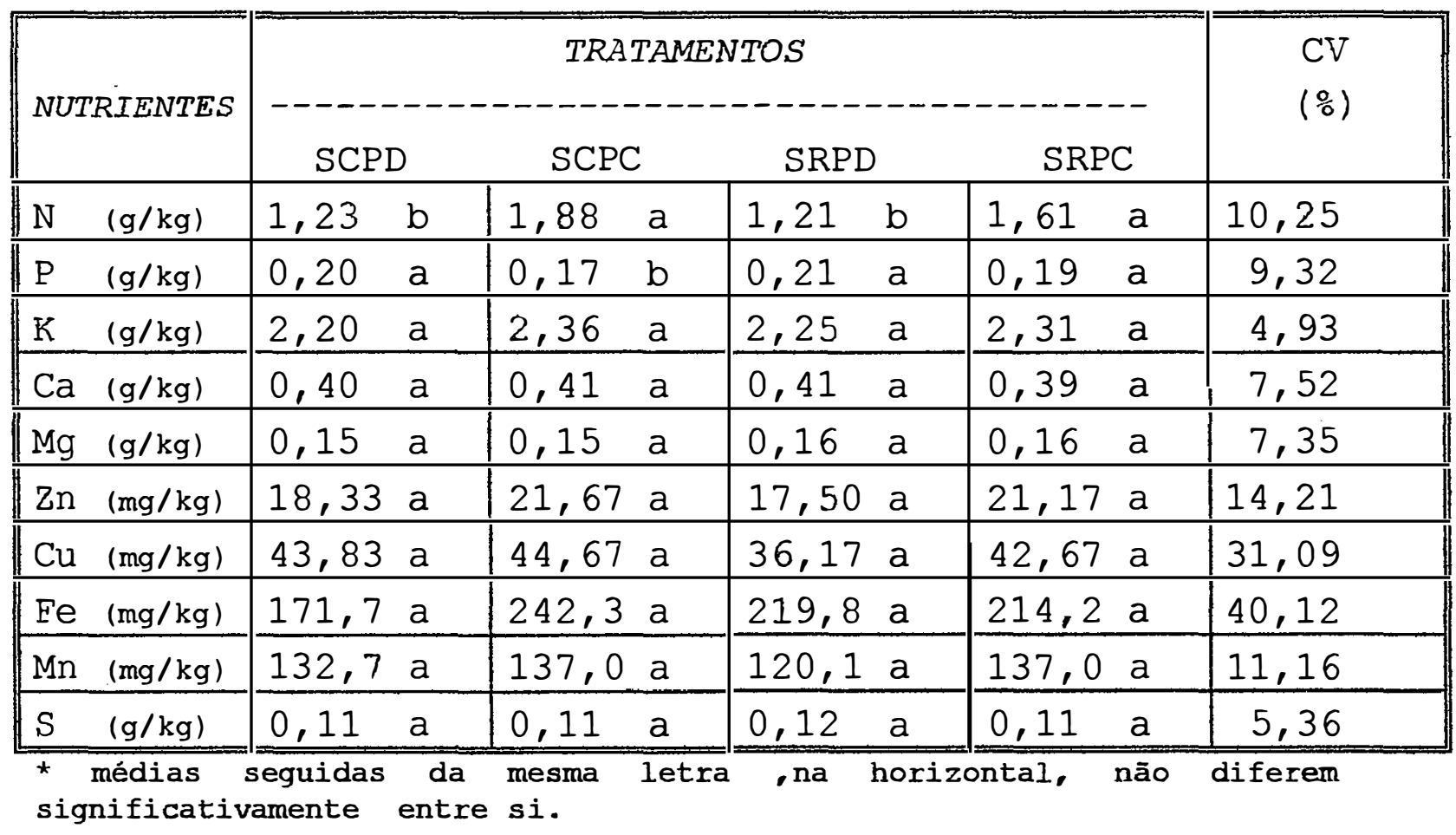

$\mathrm{Na}$ cultura de aveia preta e soja o teor de $P$ na parte aérea foi superior para as culturas sob plantio direto (Tabela 17, 18 e 19). Este fato pode estar relacionado que no plantio direto teve-se uma maior disponibilidade de $P$ no solo (Tabela 6) quando comparado ao PC e, portanto, maior absorção de $\mathrm{P}$ pelas plantas em solo sob PD.

O teor de Ca e Mg na cultura de soja e aveia preta, para alguns casos, foram maiores em solo sob PD do que em solo sob PC (Tabela 17, 18 e 19). Houve também em solo sob PD maior disponibilidade de $\mathrm{Ca}$ e Mg (Tabela 6), tendo estas culturas um maior teor disponível desses nutrientes para a sua absorção. 
Para os demais nutrientes ( $k, \mathrm{Zn}, \mathrm{Cu}$, $\mathrm{Fe}, \mathrm{Mn}$ e S) da parte aérea para cultura de aveia preta e soja não houve diferença significativa para os diferentes tratamentos.

\subsection{Produção da soja e aveia-preta}

Verificou-se que para os diferentes tratamentos não houve diferença significativa na produção, para a cultura de soja como para a aveia preta, portanto, o sistema de manejo do solo não afetou a produção de soja e aveia (Tabela 20). Em alguns anos agrícolas anteriores, nessa mesma área do presente estudo, verificou-se diferenças significativas na produção de aveia e soja entre os diferentes sistemas de manejo do solo (CASTRO, 19941). Para a produção de palha de aveia preta houve um coeficiente de variação alto, podendo ter interferido nas diferenças de produção entre os tipos de manejo. CALEGARI et al., 1994 e TORRES et al., 1994 verificaram uma superioridade de produção da soja sob plantio direto quando comparado com $\circ$ preparo convencional.

1 CASTRO, O.M. (Instituto Agronomico de Campinas, IAC, Campinas,SP). Comunicação Pessoal, 1994. 
Tabela 20 - Produção de grãos de soja e matéria seca de aveia-preta, na região de Campinas/sP. (média de 2 repetições).

\begin{tabular}{|c|c|c|c|c|}
\hline \multirow[t]{2}{*}{ TRATAMENTO } & \multicolumn{2}{|c|}{$\begin{array}{c}\text { SOJA }(07 / 05 / 93) \\
-\end{array}$} & \multirow{2}{*}{$\begin{array}{c}\text { AVEIA-PRETA } \\
(07 / 10 / 93) \\
\text { PALHA (kg/ha) }\end{array}$} & \multirow{2}{*}{$\begin{array}{c}\text { AVEIA-PRETA } \\
(07 / 11 / 92) \\
\text { PALHA (kg/ha) }\end{array}$} \\
\hline & PALHA & GRÃO & & \\
\hline SCPD & $3775 a$ & 1924 a & $3492 a$ & 2977 a \\
\hline SCPC & $4060 \mathrm{a}$ & $1888 \mathrm{a}$ & $2093 \mathrm{a}$ & $3188 \quad \mathrm{a}$ \\
\hline SRPD & $3867 \mathrm{a}$ & $2133 a$ & $3568 \quad \mathrm{a}$ & $3156 \mathrm{a}$ \\
\hline SRPC & $4680 \mathrm{a}$ & $2617 \mathrm{a}$ & $2149 \mathrm{a}$ & $3008 \quad \mathrm{a}$ \\
\hline $\mathrm{CV}\left(\frac{\circ}{0}\right)$ & 6,23 & 7,24 & 38,49 & 25,95 \\
\hline $\mathrm{PD}$ & $3821 \mathrm{a}$ & $2028 \quad a$ & $2121 \mathrm{a}$ & $2568 \quad \mathrm{a}$ \\
\hline $\mathrm{PC}$ & $4370 \mathrm{a}$ & $2252 a$ & $3530 \mathrm{a}$ & $2649 a$ \\
\hline $\mathrm{CV}\left(\frac{\circ}{0}\right)$ & 8,26 & 17,21 & 37,0 & 10,74 \\
\hline
\end{tabular}




\section{CONCLUSÕES}

- o plantio direto apresentou os maiores valores de : biomassa microbiana, atividade de desidrogenase do solo, teores de matéria orgânica e fósforo no solo, e uma tendência maior na contagem de microrganismos do solo, principalmente na camada superficial do solo;

- Houve pouca nodulação e micorrização da soja, embora as causas permaneceam desconhecidas, enquanto que a porcentagem de colonização micorrízica na aveia foi relativamente alta. A espécie de Scuttelospora gregaria foi predominante no ensaio;

- Não houve diferenças na produção de soja e aveia para os diferentes sistemas de manejo do solo;

- Através da atividade de desidrogenase do solo pode-se estimar a biomassa microbiana;

- o plantio direto envolve uma redução de preparo de solo (menor custo de operação), sendo muito eficiente no controle da erosão do solo e também mostra ter ativação da microbiota do solo principalmente na camada superficial; por estes motivos o plantio direto poderia ser indicado preferencialmente, especialmente em solos mais sujeitos à erosão, mesmo que não cause necessariamente um aumento da produtividade da cultura. 


\section{REFERÊNCIAS BIBLIOGRÁFICAS.}

ABBOT, L.K. \& ROBSON, A.D. The distribution and abundance of vesicular-arbuscular endophtes in some Westrn Auustralian soils. Australian Journal of Botany, Victoria, 25:515-22, 1977.

ANDERSON, J.P.E. \& DOMSCH, K.H. A physiological method for the quantitative measurement of microbial biomass in soil. Soil Biology Biochemitry, Oxford, $10: 215-21,1978$.

ANTUNES, V.; SILVEIRA, A.P.; CARDOSO, E.J.B.N. Interação entre diferentes tipos de solo e fungos micorrízicos vesículo-arbuscular na produção de mudas de café (Coffea arabica, L.). Turrialba, San José, 38:2,117-22, 1988.

BENATTO JUNIOR, R.; BERTONI, J.; MOREIRA, C.A. Perdas por erosão em plantio direto e convencional de milho em 2 solos do Estado de São Paulo. Revista Brasileira de Ciência do Solo, Campinas, 1:121-3, 1977 . 
BLACK, L. \& THINKER, K. The development of endomicorrhiza root systems II: effects of agronomic factors and soil conditions on the development of vesicular-arbuscular mycorrhizal infection in barley and on the density, New Phytologist, oxford, $83(2): 401-14,1979$.

BLEVINS, R.L.; COOK, D.; PHILLIPS, R.E. Influence of tillage on soil moisture. Agronomy Journal, Madison, $63: 593-6,1971$.

BLEVINS, R.L.; THOMAS G.W.; CORNELUS, P.L. Influence of no-tillage and nitrogen fertilization on cerain soil properties after 5 years of continous corn. Agronomy Journal, Madison, 69:383-6, 1977.

BLEVINS, R.L.; SMITH, M.S.; THOMAS, G.W.; FRYE, W.W. Influence of conservation tillage on soil properties. Jounal of Soil Water Conservation, Ankeny, 38:301-5, 1983.

BOLTON, H.; ELLIOT Jr., L.F.; PAPENDICK, R.I.; BEZDICEK, D.F. Soil microbial biomass and selected soil enzymes activities: effect of fertilization and cropping pratices. Soil Biology Biochemitry, Oxford, $17: 297-302$, 1985 .

BONONI, V.L.R.; BARBOSA, L.M.; VIRIATO, A. Micorrizas vesículo-arbusculares em amendoim e em plantas invasoras da cultura. Hoehnea, São Paulo, 15:1-9, 1988 .

BONONI, V.L.R. \& TRUFEM, S.F.B. Endomicorrizas vesiculo-arbusculares do Cerrado da reserva biológica de Mogi-Guaçu, SP, Brazil. Rickia, São Paulo, 10:55-84, 1983. 
BREMNER, J.M. Inorganic forms of nitrogen. In: BLACK, C.A., ed. Methods of soil analysis. Madison, American Society of Agronomy, 1965. Pt.2: Chemical and microbial properties, p.1179-237.

BROSE, E. \& FREIRE, J.R.J. Efeito de umidade e luminosidade sobre a atividade de nódulos de soja (Glycine max Merr.). In: REUNIÃO CONJUNTA DE PESQUISA DE SOJA, 4., Santa Maria, 1976. Ata. Porto Alegre, APAGRO, 1976. p.31-40.

BURNS, R.G. Enzyme activity in soil: location and a possible role in microbial activity. Soil Biology Biochemistry, Oxford, 14:423-7, 1982.

BURNS, R.G. Soil enzymes. London, Academic Press, 1978. $380 \mathrm{p}$.

CALEGARI, A; FERRO, M.; GRZESIUK, F.; JACINTO Jr., L. Efeito do manejo e da rotação de culturas na caracteristícas físicas do solo e rendimentos dos cultivos. In: REUNIÃO DE PESQUISA DE SOJA DA REGIÃO CENTRAL DO BRASIL, 15., Londrina, 1993. Ata, Londrina, (Embrapa/CNPSo - Documento 72), 1994. p.31-2.

CAMPBELL, C.A. \& BIEDERBECK, V.O. Soil bacterial e changes as effected by growing season wea ther conditions: a laboratory field study. Canadian Journal Soil Science, Ottawa, 56:23-30, 1976.

CAMPBELL, C.A. Changes in mineral $\mathrm{N}$ and numbers of bacteria and actinomycetos during two years under wheat-fallow in southwesths saskatchewar. Canadian Journal Soil Science, Ottawa, 62:125-35, 1982. 
CANNEL, R.Q. \& FINNEY, J.R. Effects of direct drilling and reduced cultivation on soil conditions for root growth. Outlook on Agriculture, Oxford, 6:184-9, 1979.

CARDOSO, E.J.B.N. Eficiência de fungos micorrízicos vesiculo-arbusculares em soja, com Rhizobium japonicum e fosfato de rocha, em função do tipo de solo. Revista Brasileira de Ciência de Solo, Campinas, 10:17-23, 1986.

CARDOSO, E.J.B.N. Efeito de micorriza vesículoarbuscular e fosfato de rocha na simbiose sojaRhizobium. Revista Brasileira de Ciência do Solo, Campinas, 9:125-30, 1985.

CARTER, M.R. Microbial biomass as an endex for tillage-induced changes in soil biological properties. Soil Tillage Residual, Amsterdan, 7: 2940, 1986.

CARTER, M.R. \& RENNIE, D.A. Changes in soil quality under zero tillage forming systems: distribution of microbial biomass and mineralizable $\mathrm{C}$ and $\mathrm{N}$ potentials. Canadian Journal Soil Science, Ottawa, 62 : 587-97, 1992 .

CASIDA Jr., L.E; KLEIN, D.A.; SANTORO, T. SOIl dehydrogenase activity. Soil science, Baltimore, $89: 371-6,1964$.

CASIDA Jr., L.E. Microbial metabolic activity in soil as measured by dehydrogenase determinations. Appl. Envirom. Microbiology, 34:630-36, 1977. 
CASTRO, O.M.; PRADO, H.; SEVERO, A.C.R.; CARDOSO, E.J.B.N. Avaliacão da atividade de microrganismos do. solo em diferentes sistemas de manejo do soja. Ciência Agrícola, Piracicaba, 50(2):212-219, 1993.

CASTRO, O.M.; CAMARGO, O.A. de; VIEIRA, S.R.; DECHEM, S.C.F.; CANTARELLA, H. Caracterização química e física de dois latossolos en plantio direto e convencional. Campinas, Instituto Agronômico, 1987 23p. (IAC. Boletim Científico, 11).

CASTRO, O.M.; CAMARGO, O.A.de; CANTARELLA, A.H.; VIEIRA, S.R.; DECHEN, S.C.F. Teores de zinco, cobre, manganês e ferro em dois latossolos sob plantio direto e convencional. Bragantia, Campinas, $51(1): 77-84,1992$.

CASTRO, O.M.; LOMBARDI NETO; QUAGGIO, JA.; DE MARIA, I.; VIEIRA, S.R. Perdas por erosão de nutrientes vegetais na sucessão soja/trigo em diferentes sistemas de manejo. Revista Brasileira de Ciências de Solo, Campinas, 10:293-7, 1986a.

CASTRO,O.M.; LOMBARDI NETO, F.; VIEIRA, S.R.; DECHEN, S.C.F. Sistemas conservacionistas e reduzidos de prepararo de solo e as perdas por erosão. Revista Brasileira de Ciências de Solo, Campinas, 10:167-71, $1986 \mathrm{~b}$.

CATELLANO, S.P. \& DICK, R.P. Influence of cropping and sulfur fertilization on transformations of sulfur in soils. Soil science society of America Journal, Madison, 55:283-5, 1991. 
CATTELAN, A.J. \& BORKET, C.M. Biomassa e população microbiana em latossolo submetido a diferentes níveis de $K$, com sucessão trigo/soja. In: REUNIÃO DE PESQUISA DE SOJA DA REGIÃO CENTRAL DO BRASIL, 15., Londrina, 1993. Ata, Londrina, (Embrapa/CNPSo Documento 72) 1994. p.19-20.

CATTELAN, A.J. \& GAUDÊNCIO, C. de A. Biomassa e população microbiana em latossolo submetido à rotação e sucessão de culturas com a soja, no sistema de semeadura direta. In: REUNIÃO DE PESQUISA DE SOJA DA REGIÃO CENTRAL DO BRASIL, 15., Londrina, 1993. Ata , Londrina, (Embrapa/CNPSo - Documento 72), 1994. p.41-2.

CATTELAN, A.J. \& TORRES, E. Biomassa e população microbiana em latossolo submetido a diferentes preparos do solo com sucessão trigo/soja. In: REUNIÃO DE PESQUISA DE SOJA DA REGIÃO CENTRAL DO BRASIL, 15., Londrina, 1993. Ata, Londrina, (Embrapa/CNPSo - Documento 72), 1994. p.42.

CATTELAN, A.J. \& VIDOR, C. Sistemas de culturas e a população microbiana do solo. Revista Brasileira de Ciência do Solo, Campinas, 14:125-32, 1990b.

CATTELAN, A.J. \& VIDOR, C. Flutuações na biomassa, atividade e população microbiana do solo, em função de variações ambientais. Revista Brasileira de Ciência do Solo, Campinas, 14:133-42, 1990a.

CENTURION, J.F. \& DEMATTÊ, J.L.I. Efeito de sistemas de preparo nas propriedades físicas de um solo sob cerrdo cultivado com soja. Revista Brasileira de Ciência do Solo, Campinas, 9: 263-66, 1985. 
CLARKE, C. \& MOSSE, B. Plant growth responses to vesicular-arbuscular mycorrhiza. New Phytologist, Oxford, 87: 695-703, 1981.

COSTA, S.M.G. \& BONONI, V.L.R. Fungos filamentosos e micorrízicos vesículo-arbusculares de solo da região degradada de Cubatão, SP, Brasil. Hoehnea, São Paulo, $18(1): 61-76,1991$.

CRUSH, J.R. Plant growth responses to vesiculararbuscular mycorriza. VII. Growth and nodulation of some nerbage legumes. New Phytologist, Oxford, 73:743-52, 1974 .

DE MARIA, I. \& CASTRO, O.M. de. Fósforo, potássio e matéria orgânica em um latossolo roxo, sob sistemas de manejo com milho e soja. Revista Brasileira de Ciência de Solo, Campinas, 17:471-77, 1993.

DICK, R.P.; MYROLD, D.D.; KERLE, E.A. Microbial biomass and soil enzyme activities in compacted and rehabilitated skid trail soils. Soil science society of American Journal, Madison, 52:512-6, 1988a.

DICK, R.P.; RASMISSEN, P.E.; KERLE, E.A. Influence of lon-term residue management on soil enzyme activity in relation to soil chemical properties of a wheatfallow system. Biology and Fertility of Soils, Berlin, 6:159-64, 1988b.

DICK, R.P. \& TABATABAI, M.A. Hydrolysis of polyphosphates by corn roots. Plant and Soil, The Hague 94:247-56, 1986. 
DICK, W.A. Influence of long-term tillage and crop rotation conbinations on soil enzyme cativities. Soil Science Society of America Journal, Madison, 48:569-74, 1984 .

DORAN, J.W. Soil microbial and biochemical changes assocated with reduced tillage. Soil science Society America Journal, Madison, 44:765-71, 1980.

ELTZ, F.L.F.; PEIXOTO, R.T.G.; JASTER, F. Efeito de sistemas de preparo do solo nas propriedades físicas e químicas de um latossolo bruno álico. Revista Brasileira de Ciência do Solo, Campinas, 13: 259$67,1989$.

ELYNCH, J.M. \& PANTING, L.M. Cultivation and the soil biomass. Soil Biology Biochemistry, Oxford, 12:54750,1980 .

EZETA, F.N. \& CARVALHO P.C.I. Influência de endomicorrizas na absorção de $P$ e $K$ e no crescimento da mandioca. Revista Brasileira de Ciência do Solo, Campinas, 6:25-8, 1982 .

FERNANDES, A.B.; SIQUEIRA, J.O.; MENEZES, M.A.L.; GUEDES, G.A.A. Efeito diferenciado do fósforo sobre - estabelecimento e efetividade da simbiose emdomicorrízica em milho e soja. Revista Brasileira de Ciência do Solo, Campinas, 11:101-8, 1987.

FERRAZ, J.M.G. Levantamento de micorriza vesículoarbuscular em culturas da Amazônia. Revista Brasileira de Ciência do Solo, Campinas, 3(3):194-6, 1979. 
FIALHO, J.F.; BORGES, A.C.; \& BARROS, N.F. Cobertura vegetal e as caracteristicas químicas e físicas e atividade da microbiana de um latossolo vermelho escuro distrófico. Revista Brasileira de Ciência do Solo, Campinas, 15:21-8, 1991.

FIEGL, B.J. Dinâmica da matéria orgânica do solo an sucessão floresta/pastegem na Amazônia (Rondônia). Piracicaba, 1994, 68p. (Doutorado - "Centro de Energia Nuclear na Agricultura "/USP).

FOLLET, R.F. \& PETERSON, G.A. Surface soil nutrient distribution as affected by wheat-fallow tillage systeams. Soil Science Society America Journal, Madison, 52: 141-7, 1988.

FRANKENBERGER, W.T. \& DICK, W.A. Relation-ships between enzyme activities and microbial growth and activity indices in soil. Soil science society of America Journal, Madison, 47: 945-51, 1983.

FREIRE， J.R.J.; KOLLING， J.; VIDOR，C.; PEREIRA， J.S.; KOLLING, I.G.; MENDES, N.G. Sobrevivência e competicão por sítios de nodulação de estirpes de Rhizobium japonicum na cultura da soja. Revista Brasileira de Ciência do Solo, Campinas, 7:47-53, 1983.

FREIRE, J.R.J. Fixação do $\mathrm{N}$ pela simbiose rizóbio/leguminosas. In: CARDOSO, E.J.B.N.; TSAI, S.M.; NEVES, M.C. Microbiologia do solo. Campinas, Sociedade Brasileira de Ciência do Solo, 1992. p. $121-40$. 
GERALDES, A.P. de A. C, $N$ e biomassa microbiana do solo em uma cromossequência floresta-pastagem em Paragominas, Para (Amazonia Oriental). Piracicaba, 1994. 68p. (Mestrado-Universidade de São Paulo/USP).

GERDEMANN, J.W. \& NICOLSON, T.H. Spores of mycorrhizal endogone species extracted from soil by wet sieving and decanting. British Mycological Society Transations, London, 46(2): 235-44, 1963.

GIOVANNETTI, M. \& MOSSE, B. An evaluetion of tecniques for measuring VA mycorrhizal infection in roots. New Phytologist, Oxford, 84:489-500, 1980.

GRISI, B.M. Comparação dos métodos de fumigação, taxa de respiração em relação a adição de glicose e conteúdo de ATP para estimar a biomassa microbiana do solo. Revista Brasileira de Ciência do solo, Campinas, 10:109-15, 1986.

GRISI, B.M. Metodologia de determinacão da biomassa microbiana do solo. Revista Brasileira de Ciência do Solo, Campinas, 8:167-72, 1984.

GRISI, B.M. \& GRAY, R.T.G. Comparação dos métodos de fumigação, taxa de respiração em resposta à adubação de glicose, e conteúdo de ATP para estimar a biomassa microbiana do solo. Revista Brasileira de Ciência do Solo, Campinas, 10:109-15, 1986.

GRISI, B.M. \& GRAY, T.R.G. Biomassa microbiana de solo estimada do biovolume com o uso da microscopia de fluorescência. Revista Brasileira de Ciência de Solo, Campinas, 9:131-8, 1985. 
HARGOVE, W.L.; REID, J.T.; TOUCHTON, J.T.; GALLAHER, R.N. Influence of pratices in the fertility status of an acid soil doublecropped with wheat and soybeans. Agronomy Journal, Madison, 74: 684-7, 1982 .

HAYMAN, D.S. \& STOVOLD, D.E. Spore populations and infectivity of vesicular-arbuscular mycorrhizal fungi in New South Wales. Autralian Journal of Botany, Victoria, 27:227-33, 1979.

HAYMAN, D.S. The occurrence of mycorrhiza in crops as affected by soil fertility. In: SANDERS, F.E.; MOSSE, B.; THINKER, P.B., ed. Endomycorrhizas. London, Academic Press, 1975. p.495-509.

JENKINSON, D.S. \& LADD, J.N. Microbia biomass in soil, measurement and turnover. In: PAUL, E.A.; LADD, E.A., ed. Soil biochemistry, New York, Marcel Dekker, 1981. v.5, p.415-70.

JENKINSON, D.S. \& POWLSON, L. The effect of biocidal treatments on metabolism in soil: method for measuring soil biomass. Soil Biology Biochemitry, Oxford, $8: 209-13,1976$.

JENKINSON, D.S. Studies on the decomposition of plant material in soil. IV. The effect of rate of additional. Journal of Soil Science, London, $28(3): 417-23,1977$.

LADD, J.N. Origen and range of enzymes in soil. In: BURNS, R.G. ed. Soil enzymes. London, Academic Press, 1978. p.51-96. 
LOMBARDI NETO, F. Práticas conservacionistas em microbacias. In: DRUGOVICH, M.C.; PECHE FILHO, A.; CAVALHO, L.V.R.; SILVA, P. dos, coord. Mecanização conservacionista, noções básicas. Campinas, Coordenação de Assistência Técnica Integral, 1990. p. 93-117.

LOPES, E.S.; SIQUEIRA, J.O.; ZAMBOLIM, L. Caracterizacão das micorrizas vesiculo-arbusculares (MVA) e seus efeitos no crescimento das plantas. Revista Brasileirade Ciência do solo, Campinas, $7(1): 1-8,1983 a$.

LOPES, E.S.; OLIVEIRA, E.; DIAS, R.; SCHENCK, N.C. Occurrence and distribiction of vesicular-arbuscular mycorrhizal fungi in coffe (Coffe arabica L.) plantations in central são Paulo state, Brazil. Turrialba, San José, 33(4): 417-22, 1983b.

LOPES, E.S. \& LOMBARDI, M.L.C.O. Os microrganismos do solo e o aproveitamento do $\mathrm{P}$ pelas plantas. In: Congresso Brasileiro de Ciência do Solo, 1980. Anais. p. 68-92

MAIA, L.C. \& TRUFEM, S.F.B. Fungos micorrízicos vesículo-arbusculares em solos cultivados no Estado de Pernambuco, Brasil. Revista Brasileira de Botânica, São Paulo, 13:89-95, 1990.

MALAVOLTA, E.; VITTI, G.C.; OLIVEIRA, S.A. Avaliação do estado nutricional da plantas; príncipios e aplicações. Piracicaba, Associação Brasileira para Pesquisa da Potassa e do Fosfato, 1989. 201p. 
MALHER, R.J.; BINGHAM, F.T.; PAGE,A.L.; RYAN, J.A. Cadmium enriched sewage sludge application to acid and calcareous soils: effect on soil and nutrition of lettuce, corn, tomato, and swiss chard. Journal Enviromental Qual., Madison, 11:694-700, 1982.

MARTENS, D.A.; JOHANSON, J.B.; FRANKENBERGER JR, W.T. Production and persistence os soil enzymes with repeated additions of organic residues. Soil Science, Baltimore, 153:53-61, 1992.

MARUMOTO, T.; ANDERSON, J.P.E.; DOMSCH, K.E. Mineralization of nutrients fron soil microbial biomass. Soil Biology Biochemitry, Oxford, 14:469$75,1982 \mathrm{~b}$.

MARUMOTO, T. ANDERSON, J.P.E.; DOMSCH, K.H. Decomposition of ${ }^{14} \mathrm{C}$ and ${ }^{15} \mathrm{~N}$ labelled microbial cells in soil. Soil Biology Biochemitry, Oxford, 14:461-7, $1982 \mathrm{a}$.

MELO, W.J.; PIZZAURO Jr., M.; CASIRO, M.A.B.; SHELI, L.A.; LEITE, S.A.S. Incorporação da parte aérea de sorgo ou lab-lab e atividade de amilase e de sacaridade de um latossolo vermelho escuro textura média. Revsita Brasileira de Ciência do Solo, Campinas, 13:213-17, 1989.

MELO, W.J. Enzimas no solo. In: SOCIEDADE BRASILEIRA DE CIÊNCIA DO SOLO. Campinas, 1988. p.365-378.

MENGE, J.A. Effects of soil fumigants and fungicides on vesicular-arbuscular fungi. Phytopatology, st Paul, 72:1125-32, 1982 . 
MINHONI, M.T.A.; CARDOSO, E.J.B.N.; EIRA, A.F.. Efeitos da adição de fosfato de rocha, bagaço de cana-deaçúcar, fosfato solúvel e fungo micorrízico no crescimento e na absorção de nutrientes por plantas de soja. Revista Brasileira de Ciência de Solo, Campinas, 17:173-8, 1993b.

MIRANDA, J.C.C. Influência de fungos endomicorrízicos inoculados a campo, na cultura de sorgo e soja em um solo sob cerrado. Revista Brasileira de Ciência do Solo, Campinas, 6:19-23, 1982.

MOROTE, C.G.B.; VIDOR, C.; MENDES, N.G.; PEREIRA, J.S. Melhoria da nodulacão da soja pela cobertura do solo e inoculacão com Bradyrhizobium japonicum. Revista Brasileira de Ciência do Solo, Campinas, 14:143-150, 1990 .

MOSSE, B.; STRIBLEJ, D.P.; LETACON, F. Ecology of mycirrhizae and mycorrhizal fungi. Advances in Microbiology Ecology, New York, 5:137-210, 1981.

MOSSE, B. \& BOWEN, G.D. The distribution of endogone spores in some australian and New Zeland soils and in an experimental field soil at Rothamsted. British Mycological Society Transations, London, 51:485-92, 1968.

MOSSE, B. Vesicular-arbuscular mycorrhiza research for tropical agriculture. Reserch Bulletim of the Hawaii Institute of Tropical Agricultire and Humas Resources. 194:1-85, 1979. 
MUNÉVAR， F. \& WOLLUM, A.G. Effect of high root temperature and Rhizobium strain on nodulation, nitrogen fixation, and growth of soybean. Soil Science Society America Journal, Madison, 45:113-20, 1981 .

MUZILLI, O. Influência do sistema de plantio direto comparado ao convencional, sobre a fertilidade da camada arável. Revista Brasileirade Ciência do Solo, Campinas, 7(1):95-102, 1983.

MUZILLI, 0 . O manejo da fertilidade do solo. In: Plantio direto no Estado do Paraná. Londrina, Fundação Instituto Agronômico do Paraná, 1981. p.43-53. (Circular IAPAR, 23).

NANNIPIERI, P. Criteria for measurement of microbial growth activity in soil. Soil Biology Biochemitry, Oxford, 10: 223-30, 1978 .

NUERNBERG, N.J; VIDOR, C.; STAMMEL, J.G. Efeitos de sucessões de culturas e tipos de adubação na densidade populacional e atividade microbiana do solo. Revista Brsileira de Ciência do Solo, Campinas, 8:197-203,1984.

OADES, J.M. \& JENKINSON, D.S. Adenosinetriphosphate content of the soil microbial biomass. Soil Biology Biochemitry, Oxford, 11:201-4, 1979.

OLIVEIRA, E.; SIQUIERA, J.O.; LIMA, R.D. ; COLOZZI FILHO, A.; SOUZA, P.. Ocorrência de fungos micorrízicos vesículo-arbusculares em cafeeiros das regiões do Alto Paranaiba e triângulo de Minas Gerais. Hoehnea, São Paulo $17(2) ; 117-25,1990$. 
ORGANIZAÇÃO DAS COOPERATIVAS DO ESTADO DO PARANÁ (OCEPAR), Cascavel/PR. Recomendacões técnicas para a cultura da soja no Paraná. 1994/1995. Cascavel, OCEPAR; Embrapa/CNPSO, 1994. 140p.

PALMA, M.S. \& TAUK, S.M. Enzimologia de solos. Naturalia, São Paulo, 7:7-15, 1982.

PAULA, M.A. \& SIQUEIRA, J.O. Efeito de micorrizas vesicular-arbusculares no crescimento, nodulacão e acúmulo de nitrogênio pela soja. Pesquisa Agropecuária Brasileira, Brasilia, 22(2):171-178, 1987 .

PAVAN, S.A. Biomassa microbiana e atividade de amilase em solos sob três tipos de cobertura vegetais. Jaboticabal, 1991. 79p. (Graduação - Faculdade de Ciências Agrárias e Veterinária "jÚLIO DE MESQUITA FILHO"/UNESP) .

PFENNING, L.; EDUARDO, B. de P.; CERRI, C.C. Os métodos da fumigacão-incubação e fumigação-extração na estimativa da biomassa microbiana de solos da Amazônia. Revista Brasileira de Ciência do Solo, Campinas, 16:31-7, 1992.

PHILLIPS,J.M. \& HAYMAN,D.S. Improved procedures for clearing and staining parasitie and vesicular arbuscular mycorrhizal fung for rapid assesment of infection. British Mcological Society Transactions, London, $55(11): 158-61,1970$.

RAIJ, B.V. Análise química do solo para fins de fertilidade, Campinas Fundação, Campinas, 1987. p.10. 
RAIJ, B. van.; SILVA, N.M.; BATAGLIA, O.C.; QUAGGIO, J.A.; HIROCE, R.; CANTARELA, H.; BELLINAZZI Jr., R.; DECHEN, A.R.; TRANI, P.E. Recomendação de adubação e calagem para o Estado de são Paulo, 2 ed., Instituto Agronômico, Campinas, 1992. 107p. (Boletim Técnico 100).

ROBBINS S.G. \& VOSS, R.D. Phosphorus and potassium stratification in conservation tillage systens. Journal of Soil and Water Conservation, Ankey, 46: 298-300, 1991.

ROCHA, H.M. Compêndio de defensivos agrícolas. 4 ed., São Paulo, Organização André Editora Ltda, 1993. p.391.

ROESSING, A.C. Panorana econômico da cultura da soja. In: REUNIÃO DE PESQUISA DE SOJA DA REGIÃO CENTRAL DO BRASIL, 15., Londrina, 1993. Ata. Londrina, Embrapa - CNPSo - Documento 72, 1994. p.126-7.

ROSS, D.J. \& CAIRNS, A. Effect of earthworms and ryegrass on respiratory and enzyme activities of soil. Soil Biology Biochemitry, Oxford, 14:583-7, 1982 .

ROSS, D.J. Microbial biomass estimations in soil fron tussock grasslands by therr biochem procedures. Soil Biology Biochemitry, Oxford, 12:175-83,1980.

SAITO, S.M.T.; MARTINS, E.C.S.; FREITAS, J.R.; ROSTON, A.J.. Ocorrência natural de micorriza e Rhizobium phaseoli em área com feijoeiro. Pesquisa Agropecuária Brasileira, Brasillia, 8:855-61, 1983. 
SAMPAIO, E.V.S.B.; SALCEDO, I.H.; MAIA, L.C. Limitação no cálculo de biomassa microbiana determinado pelo método da fumigação em solos com adição recente de substrato orgânico $\left({ }^{14} \mathrm{C}\right)$. Revista Brasileira de Ciência do Solo, Campinas, 10:31-5, 1986.

SAMPAIO, E.V.S.B. \& SALCEDO, I.H. Efeito da adição de $\mathrm{N}$ e palha $\left({ }^{14} \mathrm{C}\right)$ na liberação de $\mathrm{CO}^{2}$ e formação de biomassa microbiana em latossolo vermelho-amrelo. Revista Brasileira de Ciência do solo, Campinas, $6: 177-81,1982$.

SANO, S.M. Influência de endomicorrizas nativas do cerrado no crescimento de plantas. Revista Brasileira de Ciência do Solo, Campinas, 8:259,1984 .

SCHENCK, N.C. \& KINLOCK, M. Mycorrizal fungi colonizing field crops on a newly cleared woodland site. Proceedings of the American Phytopathological Society, 3:274, 1976.

SCHENCK, N.C. \& PÉREZ, Y. Manual for the identification of VA mycorrhizal fungi. Gainesville, University of Florida, Gainesville, 1987. 240p.

SCHENCK, N.C. \& SIQUEIRA, J.O. ECology of VA mycorrhizal fungi in temperature agrossystems In: North American Conference on Mycorrhiza, 7., Gainnesville, 1987. University of Florida, Gainnesville, 1987. p.2-3, 
SIDIRAS, N.; HENKLAIN, J.C.; DERPSCH, R.W. Comparison of three diffrent tillage systems with respect to aggregate stability, the soil and water conservation, and the yields of soybean and wheat on an oxisol. In: The Conferende of the International soil tillage reserch organization (ISTRO), 9., Osjek, 1982. (Londrina, IAPAR) 1982. p.537-44 (IAPAR. Contribuição 53).

SIDIRAS, N.; VIEIRA, S.R.; ROTH, C.H. Determinação de algumas caracteristicas físicas de um latossolo roxo distrófico sob plantio direto e preparo convencional. Revista Brasileira de Ciência do Solo, Campinas, 6:265-8, 1984 .

SIDIRAS, N. \& PAVAN, M.A. Influência do sistema de manejo na temperatura dosolo. Revista Brasileira de Ciência de Solo, Campinas, 8:265-8, 1983.

SILVA, F. \& VIDOR, C. As práticas demanejo de solo na populacão microbiana. Revista Brasileira de Ciência do Solo, Campinas, 8:291-6, 1984.

SILVEIRA, A.P.D. Micorrizas. In: CARDOSO, E.J.B.N.; TSAI, S.M.; NEVES, M.C.P. Microbiologia do solo, Campinas, Sociedade Brasileira de Ciência do Solo, 1992. p.257-96.

SIQUEIRA, J.O.; COLOZZI FILHO, A.; OLIVEIRA, E. Ocorrência de micorrizas vesicular-arbusculares em agro e ecossistemas do Estado de Minas Gerais. Pesquisa Agropecuária Brasileira, Brasilia, $24(12): 1499-506,1989$. 
SIQUEIRA, J.O. \& COLOZZI FILHO, A. Micorrizas vesiculo-arbusculares em mudas de cafeeiro II efeito do $P$ no estabelecimento e funcionamento da simbiose. Revista Brasileira de Ciência do Solo, Campinas, 10:207-21, 1986.

SIQUEIRA, J.O. \& FRANCO, A.A. Biotecnologia do solo: fundamentos e perspectivas. Lavras, ESAL, 1988. $235 p$.

SKUJINS, J.J. Extracellular enzymes in soil. Crit. Rev. Microbial, 4:383-421, 1976.

SKUJINS, J. Dehydrogenase: an indication of biological activities in arid soils. Bull Ecology Res. Commun., Stocknolm, 17:235-41, 1973 .

SKUJINS, J. History of abiontic soil enzime research. In: BURNS, R.G., ed. Soil enzymes. New York. Academic Press, 1978. p.1-39.

STEFANIC, F.; ELIADE, G.; CHIRNOGE, I. Researches concerning a biological index of soil fertility. In: SYMP. ON SOIL BIOLOGY, 5, Bucharest, 1981. Bucharest, Romanian National Soc. of Soil Science, 1984 .

STEVENSON, I.L. Dehydrogenase activity in soil. Canadian Jounnal of Microbiology, Ottawa, 5:228-35, 1959 .

STEVENSON,I.L. The effect of decomposition of various crop plants on the metabolic activity of the soil microflora. Canandian Journal Biology, Ottawa, $8: 501-9,1962$. 
TABATABAI, M.A. Soil enzymes. In: PAGE, A.L., ed. Methods of soil analysis. 2. ed. Madison, ASA/SSSA, 1982. Pt2: p.903-45. (Agronomy Monographr, 9).

THOMAS, G.M. Fertilization an liming. In: PHILIPS, R.E. ed. No-tillage research: research reports and reviens. Univ. Kentucky. College of Agriculture and Agriculture Experimental Station, Lexinngton. 1980. p. 43-54.

THOMAZINI, L.I. \& CASAGRANDE, L. Estudo sobre a associação micorrizal em Caryocar brasiliensis camb.. Revista de Agricultura, Piacicaba, 5:5-8, 1981 .

TORRES, E.; SARAIVA, O.F.; EARIAS, J.R.B.; CATTELAN, A.J. Avaliação de sistemas de preparo do solo e rotação de culturas com a soja em latossolo roxo. In: REUNIÃO DE PESQUISA DE SOJA DA REGIÃO CENTRAL DO BRASIL, 15., Londrina, 1993. Ata, Londrina (Embrapa/CNPSo - documento 72), 1994. p.39.

TRUFEM， S.F.B.; GRANDI， R.A.P.; SILVEIRA， R.B.A.. Fungos micorrízicos vesículo-arbusculares em plantas ornamentais do jardim botânico de São Paulo, SP. Hoehnea, São Paulo, $17(1): 85-9,1990$.

TRUFEM, S.F.B.; OTOMO, H.S.; SILVEIRA, R.B.A.; CASTRO, C.E.F.; TOMBOLATO, A.F.C. Fungos micorrizícos vesículo-arbusculares em roseiras cultivadas em três municípios do Estado de São Paulo, Brasil. Hoehnea, São Paulo, 16:165-77, 1989.

TRUFEM, S.F.B. \& BONONI, V.L. Micorrizas vesículoarbusculares de culutras introduzidas em áreas de cerrado. Rickia, São Paulo, 12:165-87, 1985. 
VANCE, E.D. \& JENKINSON, D.S. Microbial biomass measurements in forest soils: determination of Kc valuer and tests of Hytotheses to explain the Failue of the cloroforn fumigation incubation method in acid soil. Soil Biology Biochemitry, Oxford, 6:68996, 1987 .

VIDOR, C.; KOLLING, J.; FREIRE, J.J.R.; SCHOLLES, D.; BROSE, E. PEDORSO, M.M.T.. Fixação biológica de nitrogênio pela simbiose entre Rhizobium e leguminosa. Porto Alegre, IAPAGRO, 1987. 51p. (IAPAGRO Boletim Técnico, 11).

VIEIRA, M.J. \& MUZILLI, O. Caracteristicas de um latossolo vermelho-securo sob diferentes sistemas de manejo. Pesquisa Agropecuária Brasileira., Brasilia, $19(7): 873-882,1982$.

VOSS, M. \& SIDIRAS, N. Nodulação da soja em plantio direto em comparação com plantio convencional. Pesquisa Agropecuária Brasileira, Brasilia, $20(7): 775-82,1985$.

WALKER, C. \& SANDERS, F.E. Taxonomic concepts in the Endoganaceae: III. The separation of Scutellosporo gen. nov. from Gigaspora Gerd \& Trappe. Mycotaxon, $27: 169-82$, 1986.

ZAMBOLIM, L. SIQUEIRA, J.O. Importância e potencial das associações micorrízicas para a agricultura. EPAMIG, 26:1-36, 1985. (Documento 26). 